University of Nebraska - Lincoln

DigitalCommons@University of Nebraska - Lincoln

\title{
Host specificity of the leaf beetle, Diorhabda elongata deserticola (Coleoptera: Chrysomelidae) from Asia, a biological control agent for saltcedars (Tamarix: Tamaricaceae) in the Western United States
}

C. Jack DeLoach

United States Department of Agriculture

Phil A. Lewis

United States Department of Agriculture

John C. Herr

USDA-Agricultural Research Service, john.herr@ars.usda.gov

Raymond I. Carruthers

USDA-Agricultural Research Service, ray.carruthers@ars.usda.gov

James L. Tracy

United States Department of Agriculture

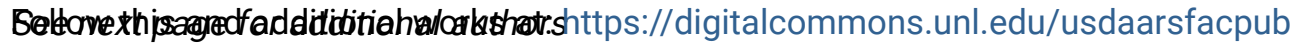

Part of the Agricultural Science Commons

DeLoach, C. Jack; Lewis, Phil A.; Herr, John C.; Carruthers, Raymond I.; Tracy, James L.; and Johnson, Joye, "Host specificity of the leaf beetle, Diorhabda elongata deserticola (Coleoptera: Chrysomelidae) from Asia, a biological control agent for saltcedars (Tamarix: Tamaricaceae) in the Western United States" (2003). Publications from USDA-ARS / UNL Faculty. 324.

https://digitalcommons.unl.edu/usdaarsfacpub/324

This Article is brought to you for free and open access by the U.S. Department of Agriculture: Agricultural Research Service, Lincoln, Nebraska at DigitalCommons@University of Nebraska - Lincoln. It has been accepted for inclusion in Publications from USDA-ARS / UNL Faculty by an authorized administrator of DigitalCommons@University of Nebraska - Lincoln. 


\section{Authors}

C. Jack DeLoach, Phil A. Lewis, John C. Herr, Raymond I. Carruthers, James L. Tracy, and Joye Johnson 


\title{
Host specificity of the leaf beetle, Diorhabda elongata deserticola (Coleoptera: Chrysomelidae) from Asia, a biological control agent for saltcedars (Tamarix: Tamaricaceae) in the Western United States
}

\author{
C. Jack DeLoach, ${ }^{\mathrm{a}, *}$ Phil A. Lewis, ${ }^{\mathrm{a}, 1}$ John C. Herr, ${ }^{\mathrm{b}}$ Raymond I. Carruthers, ${ }^{\mathrm{b}}$ \\ James L. Tracy, ${ }^{\mathrm{a}}$ and Joye Johnson ${ }^{\mathrm{a}}$ \\ ${ }^{a}$ US Department of Agriculture, Agricultural Research Service, Grassland Soil and Water Research Laboratory, \\ 808 E. Blackland Road, Temple, TX 76502, USA \\ b USDA-Agricultural Research Service, Western Regional Research Center, Exotic and Invasive Weed Research Unit, \\ 800 Buchanan Street, Albany, CA 94710, USA
}

Received 12 October 2001; accepted 18 December 2002

\begin{abstract}
Four species of saltcedars, Tamarix ramosissima Ledeb., Tamarix chinensis Lour., Tamarix parviflora DC., and T. canariensis Willd. and their hybrids, are exotic, invasive small trees from Asia that cause great damage to riparian ecosystems of the western United States. They displace native plant communities, degrade wildlife habitat (including that of many endangered species), increase soil salinity and wildfires, lower water tables, reduce water available for agriculture and municipalities, and reduce recreational use of affected areas. Phytophagous insects are abundant on saltcedar in the Old World and we selected Diorhabda elongata Brullé deserticola Chen as the top candidate biological control agent because of the great damage it causes, and its high host specificity, broad geographic range, and presumed adaptability in the United States. Literature review and our overseas surveys indicated that this insect is associated only with species of Tamarix and occasionally with Myricaria but not with Reumaria or Frankenia (all Tamaricales) in the Old World. In quarantine facilities in the United States, and overseas, we tested beetles from China and Kazakhstan on six species and three hybrids (26 accessions) of Tamarix and on 58 species of other plants, in 15 tests of different types, using 1852 adults and 3547 larvae, over 10 years. Survival from larvae to adults averaged 55-67\% on the Tamarix species, 12\% on Myricaria sp., and only $1.6 \%$ on the three Frankenia spp. No larvae completed their development on any of the other 54 plant species tested, where most larvae died during the first instar. Adults oviposited readily on T. ramosissima accessions, less on Tamarix aphylla (L.) Karst. (athel), and only rarely on other plants. The host range of the D. e. deserticola we tested from Kazakhstan was not different from those we tested from China. Therefore, D. e. deserticola, is sufficiently host-specific and was approved for field release in North America. This is the first biological control agent introduced into the United States for control of saltcedar.
\end{abstract}

Published by Elsevier Science (USA).

Keywords: Diorhabda elongata deserticola; Weeds; Biological control weeds; Host range; Saltcedar; Tamarix; Riparian ecosystems

\section{Introduction}

Saltcedars (Tamarix spp., Family Tamaricaceae) are exotic, invasive, deciduous, small trees or shrubs native

\footnotetext{
${ }^{*}$ Corresponding author. Fax: 1-254-770-6561.

E-mail addresses: jdeloach@spa.ars.usda.gov, agriffith@spa.ars. usda.gov (C.J. DeLoach).

${ }^{1}$ Present address: USDA-APHIS, Pest Survey, Detection, and Exclusion Laboratory, Otis ANGB, MA 02542, USA.
}

in the Old World. Although their foliage superficially resembles that of Juniperus spp. (commonly called cedars in the United States), the former have pink blossoms and are unrelated to junipers. Saltcedars are deeprooted, facultative phreatophytes that can reproduce vegetativity from roots or crowns if the above-ground parts are damaged, or from the copious production of small wind-blown or water-transported seeds. Their invasion of riparian ecosystems of the western United 
States causes enormous damage to natural and agricultural ecosystems.

\subsection{Evolution, world distribution, and taxonomy}

Tamarix is an ancient genus that originated during the Cretaceous Period in the Turanian and Middle Asian deserts, where it specialized in saline soils of riparian areas (Kovalev, 1995; Rusanov, 1949). Its lack of palatability to vertebrates, caused by the high tannin content of its foliage, allows it to form dominant communities (Kovalev, 1995). The genus has radiated across China (Liu and Zhang, 1987) to Mongolia and Korea and into India, and across the Middle East to the eastern Mediterranean area where a secondary major center of speciation developed, and across southern Europe to Spain, across northern Africa to Morocco and Senegal, and through eastern Africa to southern Africa (Baum, 1978). Baum (1978) recognized 54 species, none of which occur naturally in the Western Hemisphere nor in Australia.

Various taxonomists, including Rusanov (1949), earlier placed the Tamaricaceae in the orders Parietales, Guttiferales, or Primulales (Crins, 1989). However, Cronquist $(1981,1988)$ placed the Tamaricaceae (exclusively Old World) and Frankeniaceae (Australia, Chile, Eurasia, Africa, and North America) as a twofamily group within the large order Violales of subclass Dilleniidae. Then, Spichiger and Savolainen (1997), based on molecular systematics, drastically rearranged the placement of some familes in Cronquist's Violales. The new arrangement placed the Tamaricaceae and Frankeniaceae together in the two-family order Tamaricales (as some workers prior to Cronquist also had done), in the Polygonalian Lineage of the subclass Caryophyllidae, and thereby into a more distant relationship with the Violales. Also, they moved several other families, that were formerly in close proximity to the Tamaricaceae, from the order Violales to the more distantly related subclass Rosidae and even to the subclass Asteridae.

\subsection{Distribution and abundance of saltcedars in North America}

Saltcedars were first recorded in North America from a nursery catalogue in New York in 1823 and in one from California in 1856 (Horton, 1964). In the West, saltcedars were widely planted as ornamentals, for stream bank stabilization, and as windbreaks. However, they soon escaped cultivation and spread rapidly through riparian areas during the 1920s and $1930 \mathrm{~s}$. By the 1950s, they occupied more than 600,000 ha of extremely valuable riparian bottomlands along major rivers and lakeshores, often forming monotypic thickets. By the mid-1960s, they had spread from the central Great Plains to the Pacific and from northern Mexico to Montana, and were especially abundant in the southwestern United States (Horton and Campbell, 1974; Robinson, 1965). They continue to rapidly invade small tributary streams and desert springs, and they are advancing into more northern areas and into higher elevations (Lovich and de Gouvenain, 1998).

Some 10 species of saltcedars, all deciduous, small trees, 2-12 $\mathrm{m}$ tall, have been introduced into the United States over the years (Baum, 1967; Crins, 1989). (See tables for common names and authorities for plants not given in the text.) Four of these have become major noxious weeds and are targets for biological control. Tamarix ramosissima, together with $T$. chinensis, and their hybrids, are the most widespread and damaging; they are both cold- and heat-tolerant and are the predominant species from the Great Plains westward and from northern Mexico to southern Canada. Tamarix parviflora recently has become invasive and is damaging in California. Tamarix aphylla (athel) is a large, evergreen tree, to $20 \mathrm{~m}$ tall with a trunk $1.3 \mathrm{~m}$ diam, coldintolerant, and is not targeted for control (we do not categorize athel as a saltcedar). It was frequently planted in the warmer parts of the southwestern United States and northern Mexico as a drought-tolerant shade tree and for windbreaks in these desert areas. However, it is a low-quality ornamental because its limbs are brittle and it drops large quantities of dead limbs and twigs; it is less used today. Athel so far has become invasive only in a few areas and under special conditions (for example, around the Salton Sea, California, Lake Powell, Utah, and Big Bend National Park, Texas) but it has become a major pest in central Australia (Griffin et al., 1989). The other species, several of which grow in the southeastern states, are only weakly naturalized and have not become weedy (Crins, 1989; Kartesz and Meacham, 1999).

Tamarix ramosissima is native from north-central China to eastern Turkey, T. parviflora in southern Europe, and T. canariensis across northern Africa to the Canary Islands (Baum, 1978). Tamarix chinensis occurs in humid eastern China in an arc, ca. $100 \mathrm{~km}$ wide, inward from the Gulf of Bao Hai (Liu and Zhang, 1987); its occurrence in the western United States may be a recent adaptation to arid climates. $T$. ramosissima evolved with the progressive cooling and aridization of central Asia, as a plant of riverine areas and desertified savannahs; it is adapted to severe conditions of northern deserts, occurring in Asia north of the January $+8^{\circ} \mathrm{C}$ isotherm. T. aphylla occurs in southern Asia from Pakistan westward, and in northern and eastern Africa (Baum, 1978), and south of the January $+8^{\circ} \mathrm{C}$ isotherm. Both $T$. ramosissima and T. aphylla are widespread, relatively recent taxa and the ranges of the two species do not overlap (Kovalev, 1995). 


\subsection{Damage and beneficial values}

The damage caused by saltcedar was reviewed by DeLoach (1991), DeLoach and Tracy (1997), DeLoach et al. (2000), Dudley et al. (2000), Horton and Campbell (1974), and Tracy and DeLoach (1999), and is outlined briefly here. Saltcedar invasions produce drastic changes in the physical environment. Saltcedars are heavy water users that can lower water tables, reduce stream flow, and dry up desert springs. They also can increase soil salinity and wildfire frequency. During floods, they increase sedimentation and bank aggredation, narrow, block, and modify stream channel structure, eliminate backwaters, and alter water quality. Saltcedars are of major concern in the semi-arid and arid West because of their great use of water that is urgently needed by agriculture, municipalities, native plants, and wildlife. However, in extensive studies since the 1950s, investigators have had difficulties in quantifying the amount of downstream water that could be saved by saltcedar control, especially after revegetation by native high-water-using plants (reviewed by DeLoach, 1991). Recently, Zavaleta (2000) was able to estimate the value of water lost to Tamarix at \$133-285 million annually. Saltcedar infestations also reduce recreational use of parks and wildlands. These physical changes then strongly affect native riparian plant and animal communities. Here, they rapidly gain dominance and reduce biodiversity, especially in cottonwood (Populus spp.) and willow (Salix spp.) communities that are highly valuable for wildlife. Saltcedars invade both anthropogenically altered and apparently unaltered natural riparian areas. Once invaded, riparian areas usually progress inexorably toward monotypic saltcedar thickets.

Wildlife populations are harmed directly by saltcedars by the poor habitat they provide, and indirectly through changes they produce in the physical environment and to native plant communities. Most native wildlife species, especially the more specialized birds, insects, and aquatic organisms, are unable to adapt to saltcedars. They are unable to utilize saltcedar's tiny fruits and seeds and their unpalatable foliage. The stands also do not provide structure for cavity-dwelling species that are abundant in the native vegetation. Among birds, woodpeckers, raptors, and frugivores are absent in saltcedar-dominated areas, and populations of some insectivores and granivores are low and declining (Anderson and Ohmart, 1984; Hunter, 1984). Saltcedars are linked to the decline in populations of at least 41 of the 51 species of endangered or threatened animals and plants that occur in saltcedar-infested areas of the West (Anonymous, 1995; DeLoach et al., 2000; Tracy and DeLoach, 1999). Adult pollinating insects are abundant in saltcedars but immature insects and foliage-, fruit-, seed-feeding, and wood-boring species are generally absent, except for an accidentally introduced, Tamarix- specific leafhopper, two scale insect species, and two mite species from Asia. Saltcedars cause springs and small streams to dry up, forcing terrestrial animals to relocate or perish. Their degradation of stream channel structure and water quality reduces populations of aquatic plants and invertebrates. This reduces food resources, damages breeding sites, and causes population declines of many rare desert fish species and some amphibians and reptiles.

An unprecedented development in wildlife use of saltcedar habitat is the recent finding that the endangered southwestern subspecies of the willow flycatcher (Empidonax traillii Audubon subspecies extimus Phillips) has begun using saltcedars as nesting substrate, especially in some areas of Arizona (Finch and Stoleson, 2000). This is only the second case in which a highly damaging, invasive, exotic weed, proposed for biological control, has come to be utilized significantly by an endangered species (the first case was in Australia). Our analysis of the many field studies and observations indicate that this usage of saltcedar by the southwestern willow flycatcher is superficial. These relationships are described in detail by DeLoach and Tracy (1997), DeLoach et al. (2000), and Dudley et al. (2000).

Saltcedars have relatively small positive values for a few species of wildlife, mostly as nesting habitat and cover for some bird species, such as the white-winged dove (Zenaida asiatica (L.)), in areas where it has replaced the native plant communities. They also have some value as ornamentals, for honeybees, and for windbreaks and for control of stream bank erosion (reviewed by DeLoach, 1991, DeLoach et al., 2000).

\subsection{Causes of saltcedar's aggressive invasion}

Saltcedar invasions of riparian areas result from its several innate, aggressive characteristics and its unfortunate feed-forward interactions with both abiotic and biotic environmental factors. Saltcedars gain dominance over native plant communities by directly outcompeting the native plants during their growth phase and by preempting their nursery sites as flood waters recede and expose bare sand and mud bars. An important factor is that cottonwoods and willows produce seeds only for a short period in the spring, whereas most species of saltcedars produce seeds throughout most of the growing season. This gives saltcedars a strong advantage in areas of summer rains in the Southwest and below large dams where the natural high spring floods are regulated to low floods into the summer or fall. Most saltcedars can germinate whenever the floods recede but the natives cannot. Saltcedars gain a further indirect advantage through their changes to the physical environment (lowered water tables, increased soil salinity, and wildfires), the differential effects of livestock and wildlife browsing and insect attack, and even some control practices, all of which 
damage the native plants but for which saltcedar has moderate to high tolerance (reviewed by DeLoach and Tracy, 1997; DeLoach et al., 2000).

The extensive mixture of genotypes and hybridization, and possible intraspecific gene transfers in the United States, but apparently of much lesser occurrence in the Old World (Gaskin and Schaal, 2002), may contribute greatly to saltcedar's unique aggressiveness in the United States by increasing its genetic plasticity and adaptability to the new environment. Also, a lack of the effective natural enemies, especially of insects, that control saltcedar populations in the Old World give it a major competitive advantage over native plants in the United States. The latter is the only factor that can be easily changed and that may reduce saltcedar populations in the United States, through biological control.

\subsection{Risk analysis}

For this program on biological control of saltcedar, we have conducted one of the most extensive and complete risk analyses yet attempted for any biological control program. The original analysis (funded in part by USDI Bureau of Reclamation) began at Temple in 1987 with a thorough literature review, and produced a petition to the Technical Advisory Group for Biological Control Agents of Weeds (TAG) of the USDA-Animal and Plant Health Inspection Service (APHIS) (DeLoach, 1989), a formal economic analysis by Brown et al. (1989), and a final report to Bureau of Reclamation (DeLoach, 1991). This petition received TAG's recommendation for approval to proceed with the program.

A second risk analysis was in the form of a draft Biological Assessment to USDI-Fish and Wildlife Service (DeLoach and Tracy, 1997). This analysis reviewed possible effects of biological control on 51 endangered and threatened species that occur in western riparian areas infested by saltcedar, with major emphasis on the southwestern willow flycatcher. Our analysis also considered the cost of no action and allowing the damage caused by saltcedar to continue (a concept urged by Pimentel, 2000), or of herbicides used to control saltcedar that also damage the native plants. This assessment gained the concurrence of Fish and Wildlife Service to proceed with field-cage and open-field releases on an experimental basis (see Biological Control Program, below). Further analysis of currently held ecological concepts regarding the saltcedar invasion, and of the relation of saltcedar to the southwestern willow flycatcher and other endangered and threatened species, was provided by DeLoach et al. (2000).

\subsection{Conventional controls}

Control of saltcedars has been attempted with conventional chemical and mechanical methods for many years. Early herbicides were ineffective, or their use was banned, but two recent methods, aerial application of imazapyr or hand cutting and stump treatment with triclopyr, sometimes combined with bulldozing and burning, are effective (reviewed by Sisneros, 1990). However, these methods are expensive, temporary, and seriously damage the remaining native plants, especially in natural areas. Zavaleta (2000) estimated the cost of control including vegetation and monitoring at $\$ 7420$ per hectare over a 20 -year program, and that $16-50$ years would be required to recover the costs of control at a $6 \%$ discount rate.

\subsection{Biological control program}

Biological control of weeds, through introducing the natural enemies (mostly insects) that regulate the weed's population in its homeland, is an effective and safe method of weed management. It is especially useful in natural areas, forests, and rangelands, where very high specificity, low costs, and permanent control are needed to reduce populations of an invasive exotic weed without harming the native species. It has been applied against 133 weed species, using more than 350 control organisms, in 51 countries since 1865 . Worldwide, only eight examples of damage to non-target plants are known, none of which has caused serious economic or environmental damage and the majority of which were anticipated by routine testing before release. In North America, biological control has been used against some 40 weed species since 1945 , with about one third being completely or substantially controlled and another third being partially controlled (Coulson et al., 2000; Julien and Griffiths, 1999; Nechols et al., 1995; Rees et al., 1996). The philosophy and methodology of biological control of weeds has made dramatic improvements since the early 1960 s and has developed into a broadly based, logical science as outlined by Huffaker $(1957,1964)$ and others. Improvements in the concepts of host-specificity testing (Clement and Cristofaro, 1995; Harris and Zwölfer, 1968; Zwölfer and Harris, 1971), test plant selection (Wapshere, 1974), and natural enemy selection (Goeden, 1983; Harris, 1973) have resulted in both greater efficiency and greater safety. Intensive monitoring of weed biological control projects now is required in ARS projects for several years after control is initiated (Delfosse, 2000); methods of monitoring were discussed by Blossey and Skinner (2000). Regulatory direction and oversight were provided by the USDA Working Group on Natural Enemies (WGNE) in the 1960s, later broadened to the TAG in the 1970s and strengthened in the 1990s (Coulson, 1992; USDA-Animal and Plant Health Inspection Service, 1999a); the National Environmental Policy Act (NEPA) of 1969, and the Endangered Species Act (ESA) of 1973.

The USDA's Agricultural Research Service (ARS) began a program on biological control of saltcedars in 
the late 1960s (Lloyd Andres, of the former Biological Control of Weeds Investigations, ARS, Albany, California, personal communication), with cooperative projects and surveys to identify potential control agents in Israel, India, and Iran (Gerling and Kugler, 1973); Pakistan (Habib and Hasan, 1982); and Turkey (Gerling and Kugler, 1973; Pemberton and Hoover, 1980). Our research and review of literature began at Temple in 1987 (DeLoach, 1990) and at Albany in 1998.

The Russian literature lists some 325 species of insects that feed only on Tamarix, or in a few cases also on Myricaria or Reaumuria, all in the family Tamaricaceae (Lozovoi, 1961; Mityaev, 1958; Sinadsky, 1968). Many of these insects could be suitable for biological control of saltcedars in the United States (Kovalev, 1995). Additional species were reported from Tamarix in Italy by Zocchi (1971), and from our own explorations in China (R.W. Pemberton, USDA-ARS, Ft. Lauderdale, FL, in 1991 and C.J. DeLoach, 1992-1998) in cooperation with the Sino-American Biological Control Laboratory (SABCL) in Beijing.

We submitted a petition to TAG for review of conflicts of interest (DeLoach, 1989) and received a recommendation to proceed with a biological control project (letter from TAG, December 1991). In 1992, we began research on host-range testing through cooperators at the USDA-ARS European Biological Control Laboratory, Rome, Italy (later moved to Montpellier, France), at Tel Aviv University, Israel, and through cooperators at SABCL and at Hohhot, China. Research began at Ashghabad, Turkmenistan in 1993, at Almaty, Kazakhstan in 1994, and at Urumqi, China in 1996.

We began host-range testing of saltcedar biological control insects at Temple in 1992. So far, we have tested some 20 species of insects overseas, eight of which have been tested at least preliminarily under quarantine at Temple, and petitions have been submitted to TAG for field release of three species (DeLoach et al., 1996). We submitted a petition to TAG for release of the leaf beetle Diorhabda elongata Brullé deserticola Chen from western China and eastern Kazakhstan in March 1994 (DeLoach, 1994), which was recommended for approval in June (letter from A. Cofrancesco, TAG Chairman, June 1995). However, in March 1995, before the beetles were released, the southwestern willow flycatcher was placed on the Federal Endangered Species List (USDIFish and Wildlife Service, 1995). This required a Biological Assessment of the proposed release of $D$. $e$. deserticola, which was submitted to Fish and Wildlife Service (FWS) Region 2, Albuquerque, NM, in October 1997 (DeLoach and Tracy, 1997), and consultation with FWS under Section 7 of the Endangered Species Act. Our decision to proceed also included important input from the Saltcedar Biological Control Consortium, organized in November 1998, with representatives from some 40 federal and state agencies, universities, user and environmental organizations, and Native American tribes (Stenquist, 2000).

A research proposal was submitted to FWS on 28 August 1998 (DeLoach and Gould, 1998), specifying that experimental releases of D. e. deserticola would be made in field cages for 1 year at 10 sites in six western states (Texas, Colorado, Wyoming, Utah, Nevada, and California), followed by 2 years out of the cages at those sites, and with intensive monitoring to be conducted of the insects and of the native plant and animal communities for a period of 3-10 years. An Environmental Assessment was published in the Federal Register for public comment in February 1999 (USDAAnimal and Plant Health Inspection Service, 1999b). We then received a Letter of Concurrence (letter from FWS, 3 June 1999), and a Finding of No Significant Impact (FONSI) (letter from APHIS, 7 July 1999). This completed all protocols for release required under the National Environmental Policy Act as amended in 1982. APHIS issued permits for release of this biocontrol agent into field cages (not into the open environment) on 7 July and the beetles were then released into the field cages during July and August 1999. Subsequently, APHIS issued permits for release into the open field at the 10 research sites and we and our cooperators made the first releases at eight of these sites in May and June 2001.

Here, we report the results of the formal testing, as well as literature and overseas field surveys, on the host range of $D$. e. deserticola. Additional, extensive testing on the related native small desert shrubs, Frankenia spp., is reported by Lewis et al. (2003a) and information on its biology and ecology by Lewis et al. (2003b).

\section{Materials and methods}

\subsection{Test plants-selection of species}

We selected plant species used in host-range testing of D. e. deserticola according to the phylogenetic (or centrifugal) system of Harris and Zwölfer (1968) and Wapshere (1974) that now is generally accepted by biological control of weeds researchers worldwide. In addition, we included the concept of "critical" test plants, i.e., those species taxonomically within or near the normally acceptable host range (in this case within the Order Tamaricales) on which no damage or only a low level of damage is allowable. These included athel and the four species of native Frankenia, the latter more extensively tested by Lewis et al. (2003a).

Host-specificity testing of $D$. e. deserticola began in 1992 at the Temple quarantine facility. Our selection of test plants was initially based on the commonly accepted taxonomic scheme of Cronquist $(1981,1988)$ which placed Tamarix in the order Violales, subclass Dilleniidae. 
Under the phylogenetic testing system, within the closest circle of related plants we tested 23 accessions of five species and two hybrids of Tamarix from different areas of the United States, plus another species and three accessions from China. Then, in increasingly more distantly related concentric rings, we tested a species of Myricaria from China; three species of Frankenia; 15 species of 11 families of the order Violales plus four species of additional, more distantly related plant families; and 10 species of five families of saltcedar habitat associates. At the suggestion of TAG, we added five species in the families Clusiaceae, Theaceae, Primulaceae, and Plumbaginaceae, all of which formerly were placed in the orders Gutifferales, Parietales, or Primulales with the Tamaricaceae. This list of test plants was approved by TAG on 9 March 1992.

In 1998, we revised the list, following the taxonomic system of Spichiger and Savolainen (1997) which placed Tamarix in the subclass Caryophyllidae. We added species of several families of this subclass as well as additional species belonging to the plant families in the initial test-plant list. Many species of Tamarix are very similar morphologically and their identification is uncertain. For the Tamarix accessions we tested, we list the species and hybrids as identified by John Gaskin (Missouri Botanical Garden, St. Louis, Missouri) based on his nuclear DNA analysis of the fourth intron of the phosphoenolpyruvate carboxylase nuclear gene (reported in part by Gaskin and Schaal (2002)). If accessions were not analyzed by Gaskin, we used the previous identifications by B.R. Baum (Agriculture Canada, Ottawa, Canada) and/or W.L. Crins (Duke University, Durham, NC). This DNA analysis by Gaskin indicates that some of our accessions from individual field sites consisted of both $T$. ramosissima and $T$. chinensis or $T$. canariensis, or hybrids of these, or $T$. parviflora and hybrids, and various genotypes of each. These identifications are used in Section 3 and in the tables, with both old and new classification schemes designated.

The phylogenetic system of testing, together with the previous literature and field surveys and our first hostspecificity tests, indicated no need for testing habitatassociates and agricultural or horticultural plants in distantly related taxa such as the subclasses Rosidae and Asteridae. Nonetheless, we conducted several tests using 18 species of these plants in order to answer concerns of local growers near some of our proposed release sites who called for specific data to demonstrate safety. We also tested the Central Asian woody legumes, Halimodendron halodendron (salt tree) and Ammodendron bifolium (Pallas) Yakolev $(=A$. argenteum Kuntz), which had been erroneously reported in the Russian literature as a host of $D$. elongata; this testing was conducted both at Temple and by our cooperators, Drs. Ivan Mityaev and Roman Jashenko, in Kazakhstan.

\subsection{Test plants-culture}

Plants tested at the Temple facility were obtained either from seed, from cuttings of Tamarix plants growing naturally in the field, or from nursery stock. Tamarix cuttings were rooted in sand under an automatic misting machine in a greenhouse, then transplanted to $21 \times 20 \mathrm{~cm}$ (8-liter) plastic pots, in a mixture of 10 parts vermiculite, three parts topsoil, two parts peat moss, and one part sand. Plants were watered daily or as needed and fertilized once or twice a year with pellets of a slow-release fertilizer (15-9-12 N-P-K). Because of uncertainties over the identification of $\mathrm{Ta}$ marix spp. in the United States, we obtained cuttings from many naturalized stands from Louisiana to California, and grew them in pots outdoors for 1-2 years before testing. Leguminous plants used for testing at Temple were obtained from seed, as for honey mesquite and soybean, cuttings from alfalfa, or were potted plants from nursery stock, as for salt tree (H. halodendron), mescalbean, and catclaw. Plants not derived from seed had not been exposed to any pesticide treatments for at least 3 months. Plants tested at Albany were either purchased from a nursery or collected from naturalized populations in California or Colorado (see tables for scientific names).

\subsection{Location, conditions, and security of cages in the US testing areas}

At Temple, all tests with $D$. e. deserticola were conducted in the Arthropod Containment Facility (quarantine) of the USDA-ARS Grassland, Soil and Water Research Laboratory, $2 \mathrm{~km}$ south of Temple, Texas. The quarantine facility contains both laboratory space and a greenhouse, and is inspected periodically and certified by USDA-APHIS. Light-cycle in the laboratory was set at 16:8 L:D unless otherwise noted. Temperature in the quarantine laboratory was maintained until 1995 at $25 \pm 1-2^{\circ} \mathrm{C}$, and thereafter at $28 \pm 3{ }^{\circ} \mathrm{C}$; humidity ranged from 60 to $80 \% \mathrm{RH}$. The quarantine greenhouse was maintained between 21 and $28^{\circ} \mathrm{C}$ during the tests.

At Albany, tests were conducted in the quarantine greenhouse of the Exotic and Invasive Weed Research Unit located at the USDA-ARS Western Regional Research Center. Tests were conducted under natural light, with a temperature range of $16.2-26.4^{\circ} \mathrm{C}$, and humidity range of $46-60 \% \mathrm{RH}$.

\subsection{Source of insects tested}

The beetles tested in 1992 were originally collected on 17 July from two trees of $T$. ramosissima growing in the Eremophyte Botanical Garden of Academia Sinica ca. $10 \mathrm{~km} \mathrm{E}$ of Turpan (latitude $42^{\circ} 55^{\prime} \mathrm{N}$, elevation $34 \mathrm{~m})$ and ca. $160 \mathrm{~km}$ SE of Urumqi, Xinjiang Auton- 
omous Region, China. Beetles tested in 1993 were from T. ramosissima at two sites along the Urumqi highway 76 and $164 \mathrm{~km} \mathrm{NW}$ of Turpan. The Chinese beetles tested in 1999 and 2000 were from several Tamarix species at a site $7 \mathrm{~km} \mathrm{~W}$ of Fukang $\left(44^{\circ} 10^{\prime} \mathrm{N}\right.$, elevation $567 \mathrm{~m})$ ca. $50 \mathrm{~km} \mathrm{NNE}$ of Urumqi and ca. $170 \mathrm{~km} \mathrm{NW}$ of the botanical garden at Turpan. The Kazakhstan beetles tested in 1999 and 2000 originated from T. ramosissima growing near the town of Chilik, $120 \mathrm{~km}$ ENE of Almaty (latitude $43^{\circ} 33^{\prime} \mathrm{N}$, elevation $662 \mathrm{~m}$ ). Beetles from all these sites were identified as D. elongata by Dr. A.S. Konstantinov of the ARS Systemic Entomology Laboratory, later confirmed as D. e. deserticola by I.K. Lopatin, Byelorussian University, Minsk, Belarus, the world taxonomic authority for this group of leaf beetles.

All beetles obtained from overseas were brought into the quarantine facilities at Temple or Albany, where parasites, predators, or other organisms were removed. An insect pathologist (Dr. T.J. Poprawski, ARS, Weslaco, TX) examined a sample of 10-20 adults (ca. 1\%) from each overseas shipment, including any that died in transit. Occasionally, the ubiquitous insect pathogen, Beauveria bassiana (Bals.) Vuill., was present in a shipment, which was then properly cleaned and further monitored to insure that subsequent generations were pathogen free. The majority of adult insects and larvae used in tests in 2000 were shipped to both Temple and Albany from an overwintering field-cage population of $D$. e. deserticola, which has been maintained near Pueblo, Colorado since 1998 by our cooperator Debra Eberts (Ecological Research and Investigations Group, Bureau of Reclamation, US Department of the Interior, Denver, CO). The original source of these beetles was Fukang, China, obtained through the Temple quarantine facility.

\subsection{Literature review}

The literature on host range, especially the Russian and Chinese literature, was searched by one of us (Tracy) with assistance in translation and interpretation from our cooperators in Kazakhstan (Dr. Roman Jashenko), Turkmenistan (Dr. Svetlana Myartseva), and China (Dr. Baoping Li).

\subsection{Experimental design and host-specificity testing procedure}

Larval no-choice vial tests, Temple (Tests L1, L3, and L4). These tests were conducted in the Temple quarantine laboratory with a $16-\mathrm{h}$ photoperiod. One newly hatched larva of $D$. e. deserticola was placed in a $50 \mathrm{ml}$ clear plastic vial with excised foliage from one of the test plant species. The vials were examined daily, the food changed as needed, and observations made about the presence or absence (not amount) of feeding, the instar of the larva, and when death, pupation, or emergence of adults occurred. For Test L1 (1992), we observed approximately 20 larvae on each of 40 plant species and accessions (a total of 821 larvae), over a period of ca. 1 month (August) as eggs and neonate larvae became available. Larvae were obtained from a colony of adults collected 17 July 1992 from near Turpan, China and reared in the quarantine laboratory in daylight supplemented to a 16-h photoperiod. Tests L3 (June 2000) and L4 (June 1999) were conducted in a similar manner and used 12 larvae to test each of 21 or 22 different plant species and accessions. Test L3 used larvae reared from adults collected from the Bureau of Reclamation field nursery cage near Pueblo, Colorado (originally from Fukang, China), and Test L4 used neonates reared from adults of a Temple colony originally collected near Chilik, Kazakhstan.

Larval no-choice bag tests (Tests L2, L5, L6, and L7). These tests were conducted by placing neonate larvae on a branch of a healthy, potted test plant, enclosed in sleeve bags tied over the branches. The bags were made of polyester organza, $12 \times 25 \mathrm{~cm}$ or $29 \times 40 \mathrm{~cm}$, depending on the number of beetles used. The plants were 1-2 years old, planted in 8-liter pots.

Test L2, conducted at Temple in 1993, used larvae reared from beetles collected between Turpan and Urumqi, China, and reared in the quarantine laboratory with $16 \mathrm{~h}$ light. We compared larval survival and development on 16 plants, 5-20 larvae per bag, and examined weekly, tested in the quarantine greenhouse at natural photoperiod during October and November.

Tests L5 and L6 compared legumes, and was conducted in the Temple laboratory, in August 2000, at a 16-h photoperiod. In each test, we used five neonate larvae in each of 10 sleeve bags (replications), placed on four healthy, potted plants of each test-plant species. Insect survival and instar development were recorded daily. In Test L5, we compared beetles from Fukang, China on the central Asian salt tree, H. halodendron, obtained from a nursery at Ketowna, British Columbia, Canada. In Test L6, we compared beetles from Chilik, Kazakhstan on two native woody and three agricultural legumes obtained locally.

Test L7, conducted at Albany in the greenhouse, compared larval development on nine agricultural crops with that on a $T$. parviflora $\times T$. gallica hybrid. We used seven larvae per bag, replicated three times, beginning 18 June 1999. Larvae were reared from adults collected at Fukang, received at the Albany quarantine facility.

Adult host range. Five multiple-choice and one nochoice tests measured the resting/feeding and ovipositional selection responses of adults on a range of plants closely or more distantly related to $T$. ramosissima, and under a variety of conditions. 
In Test A1 (multiple-choice) at Temple, we tested adult resting, feeding, and oviposition on 10 test plants. Adults were collected near Turpan, China on 17 July 1992. They were hand-carried to Temple, and the tests were initiated on 25 and 27 July. The test was conducted in six Berkeley boxes in the quarantine laboratory with a 16-h photoperiod. These wooden boxes (60 length $\times 45$ width $\times 51 \mathrm{~cm}$ height $)$ had a sloped Plexiglas top, two muslin sleeves in the front, two screened $10-\mathrm{cm}$ ventilation holes in each side, and a 8$\mathrm{cm}$-wide screened slot across the back. Thirty unsexed adults of unknown age were placed in each of the six boxes (six replications), with two sets of 10 test-plant species (20 total) prepared as bouquets $(10-15 \mathrm{~cm}$ of cut foliage in vials of water), equally spaced, $10 \mathrm{~cm}$ apart, in a randomized design. Bouquets were replaced if they wilted. Each day we recorded adults resting on the plants and collected and weighed the frass dropped under each plant; we counted eggs laid on each plant at the end of the test, after 2 days. The beetles did not move much between plants, indicating that frass present under a plant probably was produced by beetles feeding on that plant.

In Test A2 (multiple-choice) at Temple, we compared 20 potted test plants, four accessions of T. ramosissima, four of $T$. chinensis, three of $T$. canariensis, two of $T$. aphylla, two of other Tamarix species, two Frankenia species, and three other species of Violales. The test was conducted in $1.2 \times 1.5 \times 0.5 \mathrm{~m}$ screen cages in the quarantine greenhouse in late August under natural photoperiod. We used 150 adults collected on 7 August 1993 from between Turpan and Urumqi, China, exposed to all test plants in each of four cages, tested for 2 weeks (20 August to 7 September), after which we counted the eggs on each plant.

Tests A3-A5 (multiple-choice) were conducted in China in 1995 using beetles collected at Fukang the week before. Test A3 was conducted at the SinoAmerican Biological Control Laboratory, Chinese Academy of Agricultural Sciences (CAAS), Beijing by our cooperators Dr. Qing Guang Lu and Xi Liang Jiang. In this test, 100 adults were exposed to 9 potted test plants, in each of two $80 \times 80 \times 95 \mathrm{~cm}$ nylon screen cages, placed in the laboratory garden under a shade tree, for 7 days beginning on 16 August. Tests A4 and A5 were conducted at the Grassland Research Institute, CAAS, Hohhot, Inner Mongolia, by our cooperators Jiang Feng Wang, Xi Liang Jiang, and Aiping Liu. Test A4 was set up in the laboratory and Test A5 in the institute garden beginning on 18 August, each for 7 days. In the laboratory, two $45 \times 65 \times 95 \mathrm{~cm}$ nylon mesh cages were used. The laboratory room was without temperature controls but with open windows. In each cage, 100 adults were exposed to seven potted test plants. In the garden, one $1.2 \times 1.4 \times 0.9 \mathrm{~m}$ cage was located in an open area without shade. In this cage, 274 adults were exposed to two sets of seven potted plants, each set in opposite ends of the cage.

In Test A6 (no-choice) at Temple, we tested five male and five female adults on the leguminous shrub $H$. halodendron in a $51 \times 69 \times 84 \mathrm{~cm}$ screen cage in the quarantine laboratory with a 16 -h photoperiod. Survival, oviposition, and feeding behavior were recorded twice daily for 5 days.

Adult and larval tests in Kazakhstan of erroneously reported hosts. Our cooperators in Kazakhstan conducted two no-choice tests (one of larvae and one of adults) of $D$. elongata on plants of $H$. halodendron and A. bifolium, during 2001 (Mityaev and Jashenko, 2001). Larvae or eggs were tested by placing them on plants of $H$. halodendron ca. $1 \mathrm{~m}$ tall planted the previous year on the institute grounds at Almaty or underneath Tamarix plants at the Buryndysu site, ca. $145 \mathrm{~km}$ ENE of Almaty. On 14 May, the cooperators placed 87 eggs on plants at the institute, and from 30 May to 23 June a total of 70 first-, 30 second-, and 103 third-instar larvae were placed on plants in the field at Buryndysu. From 26 April to 15 May, 220 adults were placed on plants at the institute, and from 30 May to 23 June 96 adults were placed on plants at Buryndsu. A. bifolium was tested in a similar manner. On 14 May, the cooperators placed 62 eggs and 72 adults on plants at the institute. More were not tested because of the difficulty in obtaining and culturing this plant.

\subsection{Statistical analysis}

Survival data from Tests L1-L7 were non-parametric and analyzed using a protected Kruskal-Wallis test done on the ranks of percent survival, with the mean ranks separated by the LSMEANS option of SAS PROC GLM $(P<0.05$; SAS Institute, 1990). Data from all other tests were subjected to analysis of variance using the ANOVA procedure in either SPSS or SAS, with multiple comparison of means by Fisher's protected LSD test $(P<0.05$; Norusis, 1988; SAS Institute, 1990). Data from Test A1 were subjected to an arc-sine square-root transformation.

\section{Results and discussion}

We conducted research to determine the host range of D. e. deserticola both overseas and in confinement in the United States from 1992 to 2001. We searched literature and museum records, consulted Asian taxonomic specialists, and conducted field surveys through our overseas cooperators. We conducted 15 tests to measure the host specificity of $D$. e. deserticola. Eight no-choice tests measured larval survival and development (six at Temple, one at Albany, and one in Kazakhstan), and seven tests measured host-plant selection by adult beetles (three tests at Temple, three in China, and one in Ka- 
zakhstan). Two of the US tests used beetles from Kazakhstan and the rest used beetles from China. The tests in Kazakhstan measured larval and adult survival on Halimodendron and Ammodentron, reported in the Russian literature to be hosts of $D$. elongata. Lewis et al. (2003a) report an additional 14 tests conducted to measure the suitability of Frankenia as a host plant.

\subsection{Literature records and field surveys in Asia}

In its native range, the host plants of $D$. elongata include only two genera of the family Tamaricaceae, Tamarix (Kovalev, 1995; Lopatin, 1977; Sinadsky, 1968) and Myricaria (Medvedev, 1982). These insects are known from at least 11 species of Tamarix -9 species in the published literature and at least 2-4 more recorded by us. These plants are common components of the native plant communities within the natural distribution of $D$. e. deserticola, which extends from central Gansu Province in northern China, through Kazakhstan, Kyrgyz Republic, Uzbekistan, and Turkmenistan. This area lies north of the $+8^{\circ} \mathrm{C}$ average January isotherm, as depicted by Kovalev (1995). Several other Tamarix species from this area also may be hosts.

Literature records. Lopatin (1977) reported D. elongata from, "all of Mediterranean region, Asia Minor, Mongolia. Beetles seen on Tamarix, mostly along riverbanks. Common everywhere and cause appreciable damage." Sha (1991) listed nine species of Tamarix in northwestern China as hosts, although $T$. chinensis probably is not a natural host because of its geographic isolation in eastern China (Table 1). Bao (1989) and Sha (1991) reported heavy defoliation of Tamarix by $D$. $e$. deserticola in western China. An unnamed subspecies (possibly deserticola) was reported on Tamarix in Karakalpakia, Uzbekistan, which damaged $T$. ramosissima more heavily than T. hispida (Sinadsky, 1968).

Other reported hosts in the literature are of other subspecies; D. elongata elongata from Europe and North Africa, and D. elongata sublineata and an unidentified subspecies from North Africa to Uzbekistan (Table 1). Large populations of $D$. e. sublineata were reported on Tamarix sp. in Egypt, but no estimate of damage was given (Boehm, 1908). Hosts of D. elongata reported in Europe are T. gallica, T. smyrnensis, and T. ramosissima, and in North Africa are T. africana and T. boveana (Table 1). We could find no Old World reports of $D$. elongata attacking three other common introduced species in the United States, T. chinensis, T. parviflora, or T. canariensis. Small numbers of adults and larvae have been found on Myricaria sp. in Kazakhstan and adults have been collected on Myricaria sp. in Mongolia (Medvedev, 1982); this is unimportant in North America, because Myricaria does not grow here.

Reports of $D$. elongata feeding upon leguminous shrubs in central Asia appear to be erroneous. Seitova
(1974) reported eggs, larvae, and adults of D. elongata on $A$. bifolium over three generations in the Sary Taukum Desert sands of southern Kazakhstan. Sinadsky (1968) mistakenly cited Yakhontov and Davletshina (1959) as reporting $D$. elongata feeding on the leguminous desert shrub sandy acacia, A. karelinii Fischer and C.A. Meyer, in Uzbekistan. Sinadsky (1960) reported $D$. elongata feeding upon and damaging another leguminous shrub, salt tree, $H$. halodendron, along the Syr Dar'ya River in southern Kazakhstan. However, I.K. Lopatin (letter, 1 September 2000) stated that both of these reports actually refer to Galerupipla persica (Faldermann) (formerly of the genus Diorhabda) and that $D$. elongata occurs only on Tamarix in central Asia. Lopatin (letter, 7 September 2000) collected G. persica on $A$. karelinii var. conollyi (Bunge) Yakovlev in Repetek, Turkmenistan and on H. halodendron along the Vakhsh River in southern Tadzhikistan. These new host records are unrecorded by Medvedev and Roginskaya (1988), who only list $A$. maurorum Medikus (=A. pseudalhagi Bieberstein and Alhagi camelorum Fischer) as hosts for $G$. persica. Sinadsky's (1968) report of D. elongata eggs laid on A. maurorum in Uzbekistan apparently also should refer to G. persica.

Overseas field surveys. In the present study, Dr. Bob Pemberton (USDA/ARS, Ft. Lauderdale, FL) in 1991 and one of us (DeLoach) from 1992 to 1998, together with cooperators Drs. Ren Wang and Qing Guang Lu (Sino-American Biological Control Laboratory in Beijing), Prof. Ming Ting Liu (Academica Sinica, Urumqi), and Dr. Baoping Li (Xinjiang Agricultural University, Urumqi) made extensive field surveys of the insects of Tamarix across northern China from Hebei Province in the east to western Xinjiang Autonomous Region in the west. We found $D$. e. deserticola on six species of $T a$ marix from Lanzhou in central Gansu Province westward; these were $T$. ramosissima, $T$. arceuthoides, $T$. hohenakeri, T. elongata, T. laxa, T. hispida, and T. $h$. var. karelini. The most common host was $T$. ramosissima and the largest populations were found on it. The easternmost recorded distribution for $D$. e. deserticola is Ninxia Province, China (Bao, 1989). We found no Diorhabda beetles in intensive searches on Tamarix spp. from Hohhot to Altan Xiret, Inner Mongolia in 1992, nor on $T$. chinensis in the area east and south of Tianjin in 1993. We also searched visually and made sweepings with an insect net of other nearby non-Tamarix plants at other locations but never found D. elongata on them. For example, at one major study site $7 \mathrm{~km}$ west of Fukang, Xinjiang in 1992, we made over 100 sweeps in a large stand of Reaumuria sp. in an area adjacent to a large Tamarix stand where D. elongata was common, but found no D. elongata beetles on the Reaumuria.

Our cooperators at Almaty, Kazakhstan (Prof. Ivan Mityaev and Dr. Roman Jashenko) have collected D. e. deserticola from $T$. ramosissima, T. leptostachya Bunge 
Table 1

Host and distribution records for D. elongata from the literature and from our field surveys

\begin{tabular}{|c|c|c|c|}
\hline Subspecific taxa ${ }^{a}$ & Host plants & Location & Citation \\
\hline \multirow[t]{7}{*}{$\begin{array}{l}\text { Diorhabda elongata } \\
\text { elongata (Brullé, 1832) }\end{array}$} & Tamarix gallica $\mathrm{L}$. & $\begin{array}{l}\text { France: Eastern Pyrenees; } \\
\text { Italy; Sicily }\end{array}$ & $\begin{array}{l}\text { Laboissière (1934), Lundberg } \\
\text { et al. (1987), Müller (1949-1953) }\end{array}$ \\
\hline & T. smyrnensis Bunge & Crete & Regalin (1997) \\
\hline & T. ramosissima & Bulgaria & Tomov (1969) \\
\hline & $\begin{array}{l}\text { T. africana Poiret and } T \text {. boveana } \\
\text { Bunge ( }=T \text {. bounopaea Gay } \\
\text { ex Batt. \& Trab.) }\end{array}$ & Algeria & Peyerimhoff (1926) \\
\hline & Tamarix sp. & Tunisia & Present study (see text) \\
\hline & No host listed & Tunisia & Normand (1936) \\
\hline & No host listed & $\begin{array}{l}\text { Morocco (subspp. type locality): } \\
\text { to } 2000 \mathrm{~m} \text { alt. in Atlas Mts. }\end{array}$ & Brullé (1832), Kocher (1958) \\
\hline \multirow[t]{3}{*}{$\begin{array}{l}\text { D. elongata sublineata } \\
\text { (Lucas, 1849) }\end{array}$} & Tamarix sp. & $\begin{array}{l}\text { Egypt (noted as the most } \\
\text { common galerucine) }\end{array}$ & Boehm (1908) \\
\hline & No host listed & Algeria (subspp. type locality) & Lucas (1849) \\
\hline & No host listed & Tunisia & Normand (1936) \\
\hline \multirow[t]{6}{*}{$\begin{array}{l}\text { D. elongata deserticola } \\
\text { Chen (1961) }\end{array}$} & Tamarix spp. & $\begin{array}{l}\text { China: Xinjiang Aut. Reg. } \\
\text { (subspecies type locality); } \\
\text { Ningxia Prov., Gansu Prov.; } \\
\text { Inner Mongolia }\end{array}$ & Chen (1961), Bao (1989) \\
\hline & $\begin{array}{l}\text { In order of preference: } T \text {. laxa } \\
\text { Willdenow., T. elongata Ledebour., } \\
T \text {. kansuensis Zhang, T. gracilis } \\
\text { Willdenow., T. androssowii Litvinov., } \\
T \text {. arceuthoides Bunge, T. hispida } \\
\text { Willdenow, T. smyrnensis } \\
\text { (=T. hohenackeri Bunge), } \\
\text { T. chinensis Loureiro } \\
\text { (native to East China) }\end{array}$ & $\begin{array}{l}\text { China: Xinjiang Aut. Reg.; } \\
\text { Gansu Prov.; Inner Mongolia }\end{array}$ & $\begin{array}{l}\text { Sha (1991) (host preferences } \\
\text { probably observed at the } \\
\text { Tamarix garden in the } \\
\text { Eremophyte Botanical } \\
\text { Garden of Academia Sinica, } \\
\text { near Turpan) }\end{array}$ \\
\hline & $\begin{array}{l}\text { Tamarix spp. (adults and larvae), } \\
\text { Myricaria sp. (adults) }\end{array}$ & $\begin{array}{l}\text { Mongolia: SW region, to } \\
1500 \mathrm{~m} \text { alt.; northernmost latitude } \\
\text { at Beger }\left(45.7^{\circ} \mathrm{N}\right)\end{array}$ & $\begin{array}{l}\text { Medvedev (1982) } \\
\text { (not D. e. sublineata per } \\
\text { Chen (1961)) }\end{array}$ \\
\hline & $\begin{array}{l}\text { T. ramosissima (adults most } \\
\text { abundant upon), T. arceuthoides, } \\
T . \text { hohenakeri, T. elongata, T. laxa, } \\
\text { T. hispida, and T. hispida var. } \\
\text { karelini (Bunge) Baum }\end{array}$ & $\begin{array}{l}\text { China: Gansu Prov., } \\
\text { Xinjiang Aut. Reg. }\end{array}$ & Present study (see text) \\
\hline & $\begin{array}{l}\text { T. ramosissima, } T . \text { laxa, } T \text {. gracilis, } \\
\text { T. leptostachya Bunge, } T . \text { elongata } \\
\text { and } T . \text { hispida }\end{array}$ & Kazakhstan: south Balkash Lake & $\begin{array}{l}\text { Mityaev and Jashenko (1998) } \\
\text { (identified by Lopatin) }\end{array}$ \\
\hline & $\begin{array}{l}\text { Small numbers adults and } \\
\text { larvae on Myricaria sp. }\end{array}$ & $\begin{array}{l}\text { Kazakhstan: Chilik River } \\
\text { near Masak }\end{array}$ & Mityaev and Jashenko (1997) \\
\hline \multirow{9}{*}{$\begin{array}{l}\text { D. elongata-subspecies } \\
\text { Uncertain }\end{array}$} & In order of preference: & Uzbekistan & Sinadsky (1968) \\
\hline & T. ramosissima, T. hispida & & \\
\hline & Tamarix sp. & Georgia; Azerbajan & $\begin{array}{l}\text { Lozovoi (1961), Samedov and } \\
\text { Mirzoeva (1985) }\end{array}$ \\
\hline & Tamarix sp. & Turkey; Iran & $\begin{array}{l}\text { Gerling, personal } \\
\text { communication, } 2000 \text { (not in } \\
\text { Israel); Gerling and Kugler (1973) }\end{array}$ \\
\hline & $\begin{array}{l}\text { T. aphylla (L.) Karsten and } \\
\text { Tamarix sp. }\end{array}$ & Pakistan & Habib and Hasan (1982) \\
\hline & Tamarix sp. & $\begin{array}{l}\text { Senegal: Senegal River east } \\
\text { of St. Louis is southernmost } \\
\text { latitude }\left(16^{\circ} \mathrm{N}\right)\end{array}$ & $\begin{array}{l}\text { P. Jolivet, Professor of } \\
\text { Entomology, } 67 \text { Boulevard Soult, } \\
75012 \text {, Paris, France, personal } \\
\text { communication, } 2000\end{array}$ \\
\hline & $\begin{array}{l}\text { Tamarix arceuthoides and } \\
\text { Tamarix } \mathrm{sp} .\end{array}$ & Tajikistan: $400-1800 \mathrm{~m}$ & Kulinich (1962) \\
\hline & Tamarix sp. & Uzbekistan; Turkmenistan & Present study (see text) \\
\hline & & Senegal and Sudan & Laboissière (1934) \\
\hline
\end{tabular}

${ }^{a}$ Berti and Rapilly (1973) elevated an earlier named subspecies, D. elongata carinata (Faldermann), to D. carinata (Faldermann) and separated D. carinulata (Desbrochers) from D. elongata, all of which develop on Tamarix spp. 


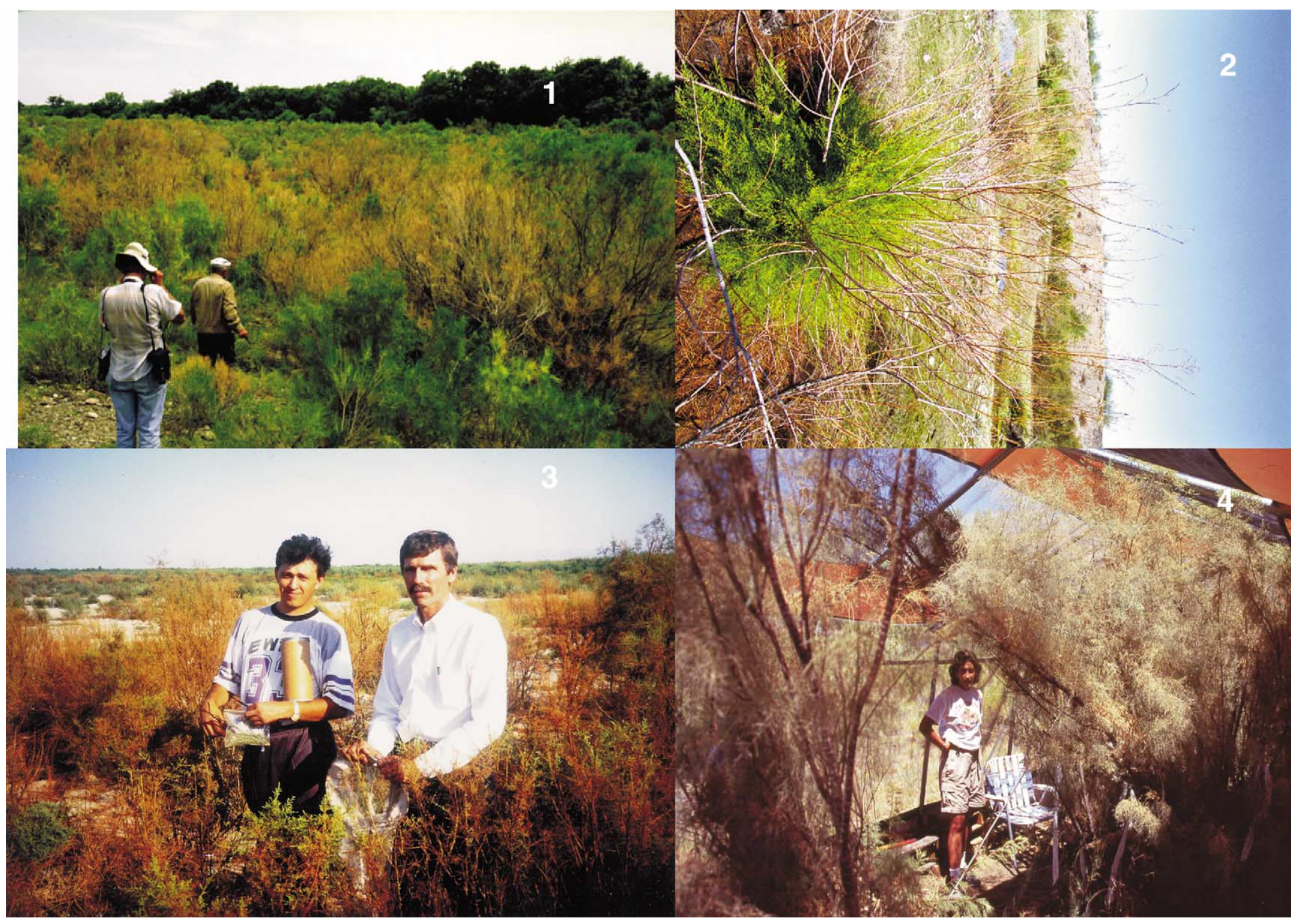

Figs. 1-4. Photographs of Tamarix plants damaged by D. e. deserticola. (1) Charyn Canyon, Kazakhstan, 19 June 1998 (C.J. DeLoach and I.D. Mityaev). (2) Die back of plant with resprouting in Chilik River Basin, Kazakhstan, August 2001 (photos 1 and 2 by R. Jashenko). (3) Dry Sport Lake, Ashgabat, Turkmenistan, August 1998 (André Averin and Allen Knutson). (4) Inside field cage near Independence, California (Technician Kathy Gerst); the larvae have severely chewed the green foliage which all died within 2 weeks (photo 4 by R.I. Carruthers). 
Table 2

Percent survival of D. e. deserticola from neonate larvae to adults on 26 Tamaricales and 53 other test plants: no-choice tests in vials or sleeve bags, Temple, TX (Tests L1-L6) or Albany, CA (Test L7), 1992-2000 a

\begin{tabular}{|c|c|c|c|c|c|c|c|}
\hline Taxonomic grouping $^{\mathrm{b}}$ & $\begin{array}{l}\text { Test L1 } \\
\text { Vial test Aug. } 92 \\
\text { Lab (Turpan } \\
\text { beetles) } n=3\end{array}$ & $\begin{array}{l}\text { Test L2 } \\
\text { Bag test Oct.-Nov. } \\
93 \text { Greenhouse } \\
\text { (Beetles 76-164 km } \\
\text { NW Turpan) } \\
n=4-6\end{array}$ & $\begin{array}{l}\text { Test L3 } \\
\text { Vial test Jun. } 00 \\
\text { Lab (Fukang } \\
\text { beetles) } n=3\end{array}$ & $\begin{array}{l}\text { Test L4 } \\
\text { Vial test Jun. } 99 \\
\text { (Kazakhstan } \\
\text { beetles) } n=3\end{array}$ & $\begin{array}{l}\text { Tests L5, L6 } \\
\text { Bag test Aug. 00 } \\
\text { Legume testing } \\
\text { (Fukang (L5) and } \\
\text { Kazakhstan (L6)) } \\
n=4-11\end{array}$ & $\begin{array}{l}\text { Test L7 } \\
\text { Bag test Aug. } 99 \\
\text { Crops, Albany } \\
\text { (Fukang beetles) } \\
n=3\end{array}$ & $\begin{array}{l}\text { Weighted average } \\
\text { for Tests } 2-6^{c}\end{array}$ \\
\hline
\end{tabular}

\section{Polygonalian Lineage}

Order Tamaricales

${ }^{\mathrm{i}}$ Family Tamaricaceae

Myricaria germanica (L.) var.

Subclass Caryophyllidae

Bracteosa (Royle);

$10.0 \pm 10.2$

Hohhot, China ${ }^{\mathrm{d}}$

(4) bc $s=44$

Tamarix aphylla (L.) Karsten

(athel) Uvalde, TX

Yuma, AZ

$0.0 \pm 0.0 \mathrm{~d}$
$S=23$

$s=23$

$5.6 \pm 9.6 \mathrm{bc}$

$s=18$

$37.2 \pm 30.5$

(6) $\mathrm{ab} s=72$

$50.0 \pm 43.3 \mathrm{bc}$

$s=12$

$83.3 \pm 14.4 \mathrm{a}$

$66.7 \pm 14.4 \mathrm{ab}$

$s=12$

$s=12$

Weighted average

\section{$65.8 \pm 28.4$}

T. austromongolica Nakai

(5) a $s=60$

Hohhot, China
T. canariensis Willd

Boca Chica, TX

$0 \pm 0 \mathrm{~d}$

(AY090435, AY090437)

(T. canariensis/T. gallica L. $)^{\mathrm{f}}$

Galveston, $\mathrm{TX}^{\mathrm{g}}$

$s=23$

Cameron Parish, LA ${ }^{\mathrm{g}}$

(AY090435, AY090437)

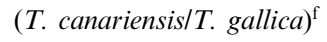

Texas City, $\mathbf{T X}^{\mathrm{g}}$

$4.8 \pm 8.2 \mathrm{c}$
$s=22$
$0 \pm 0 \mathrm{~d}$
$s=20$

$0 \pm 0 \mathrm{~d}$
$s=20$

$83.3 \pm 14.4 \mathrm{a}$
$s=12$

$83.3 \pm 14.4$
$s=12$

$48.6 \pm 28.5$

(5) a $s=62$

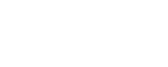

Weighted average

$$
\begin{aligned}
& 10.8 \pm 24.0 \\
& (5) \text { c } s=60 \\
& 56.0 \pm 34.8 \\
& (5) \text { a } s=61
\end{aligned}
$$

$58.3 \pm 14.4 \mathrm{ab}$

T. chinensis Loureiro

Artesia, NM (AY090386)

(ex. ramosissima)

$$
s=12
$$


(AY090386, AY090437) and/or
T. chinensis (AY090386) Pecos River/

$s=23$

I-10, TX (ex. ramosissima)

T. parviflora de Candolle

Bear Creek, CA

Crawford, $\mathrm{TX}^{\mathrm{g}}$

$s=12$

Lovelock, $\mathrm{NV}^{\mathrm{e}}$

Weighted average

T. parviflora $\times T$. gallica

Lone Pine, $\mathrm{CA}^{\mathrm{h}}$

T. ramosissima Ledebour

Bear Creek, $\mathrm{CA}^{\mathrm{e}}$

Las Cruces, $\mathrm{NM}^{\mathrm{g}}$

Lovell, WY (AY090385)

Pueblo, CO

(AY090385, AY090396) $^{\mathrm{g}}$

Yuma, $\mathrm{AZ}^{\mathrm{g}}$

\begin{tabular}{|c|c|c|c|}
\hline & $\begin{array}{l}57.7 \pm 29.7(5) \mathrm{a} \\
s=66\end{array}$ & & \\
\hline $\begin{array}{l}6.7 \pm 11.5 \mathrm{bc} \\
s=16\end{array}$ & & $\begin{array}{l}75.0 \pm 25.0 \mathrm{a} \\
s=12\end{array}$ & \\
\hline $\begin{array}{l}34.1 \pm 15.1 \mathrm{a} \\
s=20\end{array}$ & $\begin{array}{l}66.2 \pm 15.7(5) \mathrm{a} \\
s=60\end{array}$ & & $\begin{array}{l}33.3 \pm 14.4 \mathrm{~b} \\
s=12\end{array}$ \\
\hline & & $\begin{array}{l}25.0 \pm 25.0 \mathrm{~cd} \\
s=12\end{array}$ & $\begin{array}{l}83.3 \pm 14.4 \mathrm{a} \\
s=12\end{array}$ \\
\hline
\end{tabular}

$46.9 \pm 40.9(5) \mathrm{ab}$

$s=22 \quad s=64$

Weighted average

T. ramosissima $\times T$. chinensis

Stillwater NWR, NV

(AY090385, AY090386)

${ }^{\mathrm{i}}$ Family Frankeniaceae

Frankenia jamesii Torrey

ex. Gray Salt Flat, TX

Pueblo, CO

F. johnstonii Correll Laredo, TX

${ }^{\mathrm{j}} F$. salina (Molina) I.M

Johnston Point Isabel, CA

Weighted average

$$
0 \pm 0 \mathrm{~d}
$$$$
s=19
$$

$$
\begin{aligned}
& 1.4 \pm 3.4(6) \mathrm{c} \\
& s=66 \\
& 2.2 \pm 5.0(5) \mathrm{c}
\end{aligned}
$$$$
s=46
$$

$$
0 \pm 0 \text { c } s=12
$$$$
0 \pm 0 \text { e } s=12
$$$$
8.3 \pm 14.4 \text { de }
$$$$
s=12
$$

$83.3 \pm 28.8 \mathrm{a}$

$s=12$

$$
s=51
$$


Table 2 (continued)

\begin{tabular}{|c|c|c|c|c|c|c|c|}
\hline Taxonomic grouping ${ }^{\mathrm{b}}$ & $\begin{array}{l}\text { Test L1 } \\
\text { Vial test Aug. } 92 \\
\text { Lab (Turpan } \\
\text { beetles) } n=3\end{array}$ & $\begin{array}{l}\text { Test L2 } \\
\text { Bag test Oct.-Nov. } \\
93 \text { Greenhouse } \\
\text { (Beetles } 76-164 \mathrm{~km} \\
\text { NW Turpan) } \\
n=4-6\end{array}$ & $\begin{array}{l}\text { Test L3 } \\
\text { Vial test Jun. } 00 \\
\text { Lab (Fukang } \\
\text { beetles) } n=3\end{array}$ & $\begin{array}{l}\text { Test L4 } \\
\text { Vial test Jun. } 99 \\
\text { (Kazakhstan } \\
\text { beetles) } n=3\end{array}$ & $\begin{array}{l}\text { Tests L5, L6 } \\
\text { Bag test Aug. 00 } \\
\text { Legume testing } \\
\text { (Fukang (L5) and } \\
\text { Kazakhstan (L6)) } \\
n=4-11\end{array}$ & $\begin{array}{l}\text { Test L7 } \\
\text { Bag test Aug. } 99 \\
\text { Crops, Albany } \\
\text { (Fukang beetles) } \\
n=3\end{array}$ & $\begin{array}{l}\text { Weighted average } \\
\text { for Tests } 2-6^{c}\end{array}$ \\
\hline \multicolumn{8}{|l|}{ Order Plumbaginales } \\
\hline Family Plumbaginaceae & & & & & & & \\
\hline $\begin{array}{l}{ }^{\mathrm{j}} \text { Limonium limbatum Small } \\
\text { (bordered sea lavender) }\end{array}$ & $\begin{array}{l}0 \pm 0 \mathrm{~d} \\
s=20\end{array}$ & & $\begin{array}{l}0 \pm 0 \mathrm{e} \\
s=12\end{array}$ & & & & 0 \\
\hline Limonium carolinianum (Walter) & & & & $0 \pm 0 \mathrm{~d}$ & & & 0 \\
\hline $\begin{array}{l}\text { Britton (Carolina sea lavender) } \\
\text { Plumbago capensis Thundberg } \\
\text { (blue plumbago) }\end{array}$ & & & $\begin{array}{l}0 \pm 0 \mathrm{e} \\
s=12\end{array}$ & $\begin{array}{l}s=12 \\
0 \pm 0 \mathrm{~d} \\
s=12\end{array}$ & & & 0 \\
\hline \multicolumn{8}{|l|}{ Order Polygonales } \\
\hline $\begin{array}{l}\text { Family Polygonaceae } \\
{ }_{\mathrm{j}} \text { Rumex altissimus Wood } \\
\text { (smooth dock) }\end{array}$ & & & $\begin{array}{l}0 \pm 0 \mathrm{e} \\
s=12\end{array}$ & $\begin{array}{l}0 \pm 0 \mathrm{~d} \\
s=12\end{array}$ & & & 0 \\
\hline \multicolumn{8}{|l|}{ Order Simmondsiales } \\
\hline $\begin{array}{l}\text { Simmondsia chinensis (Link) } \\
\text { Schneider (jojoba) }\end{array}$ & & & $\begin{array}{l}0 \pm 0 \mathrm{e} \\
s=12\end{array}$ & & & & 0 \\
\hline $\begin{array}{l}\text { Subclass Caryophyllidae } \\
\text { Caryophyllalian Lineage } \\
\text { Order Caryophyllales } \\
\text { Family Amaranthaceae }\end{array}$ & & & & & & & \\
\hline $\begin{array}{l}\text { Amaranthus blitoides Watson } \\
\text { (prostrate pigweed) }\end{array}$ & & & $\begin{array}{l}0 \pm 0 \mathrm{e} \\
s=12\end{array}$ & & & & 0 \\
\hline $\begin{array}{l}\text { A. retroflexus } \mathrm{L} \text {. } \\
\text { (redroot pigweed) }\end{array}$ & & & & $\begin{array}{l}0 \pm 0 \mathrm{~d} \\
s=12\end{array}$ & & & 0 \\
\hline \multicolumn{8}{|l|}{ Family Chenopodiaceae } \\
\hline $\begin{array}{l}{ }^{\mathrm{j}} \text { Allenrolfia occidentalis } \\
\text { (Watson) Kuntze (pickleweed) }\end{array}$ & $\begin{array}{l}0 \pm 0 \mathrm{~d} \\
s=20\end{array}$ & & $\begin{array}{l}0 \pm 0 \mathrm{e} \\
s=12\end{array}$ & $\begin{array}{l}0 \pm 0 \mathrm{~d} \\
s=12\end{array}$ & & & 0 \\
\hline${ }^{\mathrm{j}}$ Atriplex canescens (Pursh) & $0 \pm 0 \mathrm{~d}$ & & $0 \pm 0 \mathrm{e}$ & $0 \pm 0 \mathrm{~d}$ & & & 0 \\
\hline Nutall (four-winged saltbush) & $s=21$ & & $s=12$ & $s=12$ & & & \\
\hline $\begin{array}{l}\text { Family Portulacaceae } \\
\quad \text { Portulaca oleracea L. (purslane) }\end{array}$ & & & $\begin{array}{l}0 \pm 0 \mathrm{e} \\
s=12\end{array}$ & $\begin{array}{l}0 \pm 0 \mathrm{~d} \\
s=12\end{array}$ & & & 0 \\
\hline
\end{tabular}


I Rosalian Lineage

Family Fabaceae, Mimosoideae

${ }^{\mathrm{j}}$ Acacia greggii Gray

$0 \pm 0(10) \mathrm{b}$

$s=12$

$0 \pm 0 \mathrm{~d}$

${ }^{\mathrm{j} P r o s o p i s ~ p u b e s c e n s ~ G . ~ B e n t h a m ~}$

$s=22$

(screwbean mesquite)

${ }^{\mathrm{j} P} P$. glandulosa Torrey var.

glandulosa (honey mesquite)

$0 \pm 0 \mathrm{~d}$

$s=21$

${ }^{\mathrm{j}} P$. velutina Wooten

$0 \pm 0 \mathrm{~d}$

(velvet mesquite)

$s=20$

Family Fabaceae, Papilionoideae

Glycine $\max (\mathrm{L}$.) Merrill

(soybean)

${ }^{\mathrm{j} H a l i m o d e n d r o n ~ h a l o d e n d r o n}$

(Pallas) Voss (salt tree)

Medicago sativa L. (alfalfa)

Sophora secundiflora (Ortega)

Lagasca ex. de Candolle

(mescalbean)

${ }^{\mathrm{i} F a m i l y ~ B e g o n i a c e a e}$

Begonia rex Putzeys

(king begonia)

$s=50$

iFamily Cucurbitaceae

Cucurbita pepo L.

(summer squash)

Cucumis sativus L. (cucumber)

$0 \pm 0 \mathrm{~d}$

$s=27$

$0 \pm 0 \mathrm{~d}$

$s=14$

Subclass Rosidae-Group II

Linalian Lineage

Family Clusiacea

Hypericum calycinum

$0 \pm 0 \mathrm{~d}$

$s=20$

Family Linaceae

Linum sp. (flax)

$0 \pm 0 \mathrm{~d}$
$s=24$

$s=24$

${ }^{\mathrm{i}}$ Family Flacourtiaceae

Flacourtia indica (Burm.) Merrill

$0 \pm 0 \mathrm{~d}$

(governers plum)

$s=23$

Xylosma flexuosa (Kunth) Hemsley

(brush-holly)

$s=20$

$0 \pm 0$ (10) b

$s=50$

$0 \pm 0$ (10) b

$s=50$

$0 \pm 0(10) \mathrm{b}$

$s=50$ 
Table 2 (continued)

\begin{tabular}{|c|c|c|c|c|c|c|c|}
\hline Taxonomic grouping ${ }^{\mathrm{b}}$ & $\begin{array}{l}\text { Test L1 } \\
\text { Vial test Aug. } 92 \\
\text { Lab (Turpan } \\
\text { beetles) } n=3\end{array}$ & $\begin{array}{l}\text { Test L2 } \\
\text { Bag test Oct.-Nov. } \\
93 \text { Greenhouse } \\
\text { (Beetles } 76-164 \mathrm{~km} \\
\text { NW Turpan) } \\
n=4-6\end{array}$ & $\begin{array}{l}\text { Test L3 } \\
\text { Vial test Jun. } 00 \\
\text { Lab (Fukang } \\
\text { beetles) } n=3\end{array}$ & $\begin{array}{l}\text { Test L4 } \\
\text { Vial test Jun. } 99 \\
\text { (Kazakhstan } \\
\text { beetles) } n=3\end{array}$ & $\begin{array}{l}\text { Tests L5, L6 } \\
\text { Bag test Aug. 00 } \\
\text { Legume testing } \\
\text { (Fukang (L5) and } \\
\text { Kazakhstan (L6)) } \\
n=4-11\end{array}$ & $\begin{array}{l}\text { Test L7 } \\
\text { Bag test Aug. } 99 \\
\text { Crops, Albany } \\
\text { (Fukang beetles) } \\
n=3\end{array}$ & $\begin{array}{l}\text { Weighted average } \\
\text { for Tests } 2-6^{c}\end{array}$ \\
\hline
\end{tabular}

${ }^{\mathrm{i} F a m i l y ~ P a s s i f l o r a c e a e}$

Passiflora incarnata (L.) $\quad 0 \pm 0 \mathrm{~d}$

(maypop) $s=19$

${ }^{\mathrm{i} F a m i l y ~ T u r n e r a c e a e}$

Turnera diffusa Willdenow var. $\quad 0 \pm 0 \mathrm{~d}$

aphrodisiaca (Ward) Urban $\quad s=20$

(damiana)

${ }^{\text {i}}$ Family Violaceae

Viola sororia Willdenow var. $\quad 0 \pm 0 \mathrm{~d}$

missouriensis (Greene) McKinney $\quad s=20$

(Missouri violet)

Family Salicaceae

${ }^{\mathrm{j}}$ Populus fremontii Watson $\quad 0 \pm 0 \mathrm{~d}$

$\begin{array}{ll}\text { (Fremont cottonwood) } & s=20\end{array}$

${ }^{\mathrm{j} S a l i x}$ gooddingii Ball

(Goodding willow)

Salix nigra Marshall $\quad 0 \pm 0$

(black willow)

${ }^{\mathrm{j}}$ Salix exigua Nutall

$s=21$

(coyote willow)

Subclass Rosidae

Capparalian Lineage

${ }^{\mathrm{i}}$ Family Caricaceae

Carica papaya L. (papaya)

$0 \pm 0 \mathrm{c}$

$s=20$

Subclass Rosidae

Malvalian Lineage

${ }^{\mathrm{i}}$ Family Bixaceae

Amoreuxia wrightii Gray

(Wrights yellowshow)

Bixa orellana L. (annatto)

$$
\begin{aligned}
& 0 \pm 0 \mathrm{e} \\
& s=12 \\
& 0 \pm 0 \mathrm{e} \\
& s=12
\end{aligned}
$$$$
0 \pm 0
$$

${ }^{\mathrm{i}}$ Family Cistaceae 
Subclass Asteridae

Ericalian Lineage

${ }^{\mathrm{i}}$ Family Fouquieriaceae

Fouquiera splendens

Engelemanum subsp.

Splendens (ocotillo)

Family Primulaceae

Samolus ebracteatus Kunth

Family Theaceae

Camellia japonica

$0 \pm 0 \mathrm{~d}$

L. (common camellia)

Subclass Asteridae

Gentianalian Lineage

${ }^{\mathrm{i}}$ Family Loasaceae

Cevallia sinuata Lagasca $\quad 0 \pm 0 \mathrm{~d}$

(stinging Cevallia)

$s=21$

$s=21$
$0 \pm 0 \mathrm{~d}$

Mentzelia oligosperma Nuttall

$s=22$

Commercial Crop Plants

Vitis vinifera $\mathrm{L}$. (wine grape)

Cultivar Red flame ruby seedless

Helianthus annuus L. (sunflower)

Cultivar Holiday

Juglans regia L. (English walnut)

Lactuca sativa L. (garden lettuce)

Cucumis sativus L. (Cucumber)

cultivar Cool Breeze

Prunus americana Marshall (plum)

$\begin{array}{ll}0.0 \pm 0.0 \mathrm{~b} & 0 \\ s=21 & \\ 0.0 \pm 0.0 \mathrm{~b} & 0 \\ s=21 & \\ 0.0 \pm 0.0 \mathrm{~b} & 0 \\ s=21 & \\ 0.0 \pm 0.0 \mathrm{~b} & 0 \\ s=21 & \\ 0.0 \pm 0.0 \mathrm{~b} & 0 \\ s=21 & \\ 0.0 \pm 0.0 \mathrm{~b} & 0 \\ s=21 & \end{array}$


Table 2 (continued)

\begin{tabular}{|c|c|c|c|c|c|c|c|}
\hline Taxonomic grouping ${ }^{\mathrm{b}}$ & $\begin{array}{l}\text { Test L1 } \\
\text { Vial test Aug. } 92 \\
\text { Lab (Turpan } \\
\text { beetles) } n=3\end{array}$ & $\begin{array}{l}\text { Test L2 } \\
\text { Bag test Oct.-Nov. } \\
93 \text { Greenhouse } \\
\text { (Beetles 76-164 km } \\
\text { NW Turpan) } \\
n=4-6\end{array}$ & $\begin{array}{l}\text { Test L3 } \\
\text { Vial test Jun. } 00 \\
\text { Lab (Fukang } \\
\text { beetles) } n=3\end{array}$ & $\begin{array}{l}\text { Test L4 } \\
\text { Vial test Jun. } 99 \\
\text { (Kazakhstan } \\
\text { beetles) } n=3\end{array}$ & $\begin{array}{l}\text { Tests L5, L6 } \\
\text { Bag test Aug. 00 } \\
\text { Legume testing } \\
\text { (Fukang (L5) and } \\
\text { Kazakhstan (L6)) } \\
n=4-11\end{array}$ & $\begin{array}{l}\text { Test L7 } \\
\text { Bag test Aug. } 99 \\
\text { Crops, Albany } \\
\text { (Fukang beetles) } \\
n=3\end{array}$ & $\begin{array}{l}\text { Weighted average } \\
\text { for Tests } 2-6^{c}\end{array}$ \\
\hline $\begin{array}{l}\text { Prunus dulcis (Miller) D.A. Webb } \\
\text { (almond) }\end{array}$ & & & & & & $\begin{array}{l}0.0 \pm 0.0 \mathrm{~b} \\
s=21\end{array}$ & 0 \\
\hline $\begin{array}{l}\text { Lycopersicon esculentum Miller } \\
\text { (tomato) var. VF- } 36\end{array}$ & & & & & & & 0 \\
\hline Triticum aestivum L. (wheat) & & & & & & $0.0 \pm 0.0 \mathrm{~b}$ & 0 \\
\hline Cultivar Butte & & & & & & $s=21$ & \\
\hline Total larvae tested & 821 & 935 & 252 & 252 & 338 & 210 & \\
\hline
\end{tabular}

${ }^{\mathrm{a}}$ Values are mean percentages $( \pm \mathrm{SD})$ of neonates reaching the adult stage for each plant with number of groups of larvae in parenthesis, where $n$ (statistical sample size) $=$ number of groups of vials or number of sleeve bags; and $s$, total number of individual larvae sampled from all groups; ranks of values followed by the same letter within the same column are not significantly different $(P<0.05$; Kruskal-Wallis Test on ranks using PROC GLM-LSMEANS test (SAS Institute, 1990)).

${ }^{\mathrm{b}}$ Taxonomic groupings follow angiosperm phylogeny of Spichiger and Savolainen (1997), and Tamarix follows the revision of Baum (1978) and the molecular identifications of John F. Gaskin, Missouri Botanical Garden, St. Louis, Missouri, using intron 4 of the nuclear phosphoenolpyruvate carboxylase (pepC) gene (Gaskin and Schaal, 2002). X denotes a hybrid, / denotes indistinguishable between the two species listed. The accessions followed by specimen numbers were identified by Gaskin as listed, from our potted test plants except for Pecos/I-10 that were field specimens and 1992-1993 T. chinensis and T. ramosissima accessions that were considered identical with 1999 accessions. Gaskin also identified the Lone Pine accession, but without a specimen number Accession numbers represent sequences of haplotypes of the nuclear pepC gene that are in the National Institute of Health's GenBank genetic sequence database. Accession numbers are given for each haplotype of heterozygous pepC genes, while a single accession number is given for the two identical haplotypes of homozygous pepC genes.

cAverages among tests calculated with sample size $(n)$ as a weighting factor. See text "Concensus of All Larvae Tests" for further discussion of calculations; low values for Cangzhou, China, and Seymour, TX were excluded.

${ }^{\mathrm{d}}$ Identified by Ming Ting Liu, Academia Sinica, Urumqi, Xinjiang Autonomous Region, China, and/or P. Zhang, Lanzhou University, Lanzhou, Gansu Province, China

eur identifications, not confirmed by taxonomic authorities.

${ }_{\mathrm{f}}^{\mathrm{f}}$ According to J.F. Gaskin, the two haplotypes of the heterozygous nuclear pepC gene could represent T. canariensis and/or T. gallica.

${ }^{g}$ Identifications made ca. 1992 by either B.R. Baum (Agriculture Canada, Ottawa) or W.L. Crins (Duke University, Durham, NC). If a species is listed in parenthesis it differed from the molecular identification of J.F. Gaskin. The identifications made by Baum and/or Crins were from field specimens that were not necessarily from the same tree as our test plants.

${ }^{\mathrm{h}}$ According to J.F. Gaskin, morphologically resembles $T$. gallica but the intergenic spacer region between chloroplast genes tRNA-Gly and tRNA-Ser represents $T$. parviflora.

${ }^{\mathrm{i}}$ Formerly in the order Violales that included the Tamaricaceae, per Cronquist (1981).

${ }^{\mathrm{j}}$ Habitat associates of Tamarix. 
and other Tamarix species and Myricaria in eastern Kazakhstan (specimens identified by I.K. Lopatin; letter of 30 May 2000). They have collected insects from $\mathrm{Ta}$ marix and associated flora over a wide area of the southeastern part of the country (Mityaev for over 40 years). They report that they have never collected $D$. elongata on any except Tamarix plants (letter, I.D. Mityaev, 15 August 2000). Another cooperator, Prof. Svetlana Myartseva, collected D. e. elongata on T. ramosissima and a few other Tamarix species (not identified) near Ashghabad, Turkmenistan. Our cooperators at Montpellier, France (Drs. Rouhollah Sobhian and Alan Kirk) from 14 to 19 May 2000 made visual searches and took sweep-net samples on Frankenia thymifolia Desfontaines growing near Tamarix spp. in Tunisia, where $D$. elongata was abundant, but found no $D$. elongata on the Frankenia. They also did not find $D$. elongata on $T$. parviflora or $T$. gallica in extensive searches made during several years in southern France.

The host range of $D$. e. deserticola may include more species of Tamarix than reported in the literature or found in our field surveys. Given the uncertainties in taxonomic status both of the species of Tamarix and of the subspecies of $D$. elongata, the host range of this beetle in Asia may well include other Tamarix species, and even may include all 20 species occurring within its native range. The host range of $D$. e. deserticola possibly could include many of the 54 species of Tamarix; the lack of records on other Tamarix species being only because of limited collections in many areas or because the insect has not come in contact with these species because of ecological barriers.

Both literature reports and our own surveys indicate heavy damage caused by both larvae and adults of $D$. $e$. deserticola to T. ramosissima in Asia; however, such damage appears to be very sporadic in both space and time. Sha (1991) reported such heavy damage in China that $D$. e. deserticola had to be controlled by insecticides or by winter flooding to prevent destruction of young Tamarix plantations, planted to control moving sand dunes. We (DeLoach and Chinese cooperators Ming Ting Liu and Qing Guang Lu) observed such damage to young plantations between the cities of Turpan and Urumqi in 1993.

In 1998, some of us (DeLoach and cooperators Mityaev and Jashenko) found a natural area with large plants (to $4 \mathrm{~m}$ high) of several hectares of $T$. ramosissima near the Charyn canyon site ca. $225 \mathrm{~km}$ ENE of Almaty with near total defoliation by D. e. deserticola (Fig. 1). Our cooperator in Turkmenistan (Prof. Svetlana Myartseva) along with our visiting cooperator Dr. Allen Knutson from Texas A\&M Experiment Station, Dallas, reported a similar area of defoliation in 1998 at Sport Lake, near Ashghabad (Fig. 3). Additional surveys in southern Greece (Crete) by one of us (Carruthers) in September 2001 also revealed high densities of $D$. elongata causing heavy defoliation near Khaniá and Iráklion.

\subsection{Larval host range: beetles from China}

We conducted six larval tests at Temple (Tests L1L6), and one at Albany (Test L7), from 1992 to 2000 using a wide range of test plants. These were all nochoice tests, either in vials or sleeve bags.

Test L1, Temple - vial test, laboratory, August 1992, 40 test plants, Turpan beetles. In this test, only seven adults were produced on $T$. ramosissima from Lovell, Wyoming, two from Yuma, AZ, and one on each of four other Tamarix accessions (Table 2). However, when we examined how many larvae developed to the second or third instar, the results were more meaningful: $70.6 \%$ of the larvae on T. ramosissima from Lovell reached the third instar, an average of $37.4 \%$ on the two other $T$. ramosissima accessions, $15.8 \%$ on the four $T$. canariensis accessions, $19.5 \%$ (38.9 and $0.0 \%$ ) on the two T. aphylla accessions, and $9.5 \%$ on the $T$. parviflora accession (Table 3). All other neonate larvae on the other 29 plant species died during the first instar.

Of the 229 larvae placed on the 11 Tamarix accessions, $34.3 \%$ survived to the second instar $(65.7 \%$ mortality during the first instar), $23.7 \%$ survived to the third instar (35.8\% mortality of the 95 second instars), and $6.6 \%$ (13 individuals) survived to the adult stage (78.7\% mortality of the 61 third instars). Thus, greatest mortality occurred during the first and third instars and the pupal stage (the latter mostly during molting to the pupa or to the adult).

Test L2, Temple - bag test, greenhouse, Oct.-Nov. 1993, 16 test plants, beetles from between Turpan and Urumqi. In this test, $46.9-66.2 \%$ of the larvae produced adults on the three accessions of T. ramosissima and on T. austromongolica from China, $33.3-48.6 \%$ on T. parviflora and T. canariensis, $54.7-56.0 \%$ on $T$. chinensis and its hybrid from the United States, $37.2 \%$ on $T$. aphylla, and 10.8 and $12.0 \%$ on T. chinensis and Myricaria from China. On the Frankenia jamesii plants, only one larva of 66 reached the second instar but it produced an adult. On $F$. johnstonii, only two of 46 larvae reached the second instar but one of these continued development to the adult stage. Both adults reared in this test on Frankenia were deformed. All larvae died during the first instar on the other three test-plant species (Table 2).

Test L3, Temple - vial test, laboratory, June 2000, 22 test plants, Fukang beetles. Survival from neonate larvae to the adults in this test was high, $83 \%$ on T. canariensis from Louisiana and on T. aphylla from Yuma and 75\% on $T$. ramosissima from Las Cruces. Survival was lower on $T$. aphylla from Uvalde $(50 \%)$ and on $T$. chinensis $(58 \%)$, and still lower $(25-33 \%)$ on the other two $\mathrm{Ta}$ marix species. On the seven Tamarix species and accessions tested, from 67 to $100 \%$ of the neonates 
Table 3

Survival of larvae of D. e. deserticola to the second and third instar on Tamarix species and accessions in Test L1

\begin{tabular}{|c|c|c|c|}
\hline \multirow[t]{2}{*}{ Tamarix accessions } & \multirow[t]{2}{*}{ No. of neonates tested } & \multicolumn{2}{|c|}{$\%$ Reaching instar $(X \pm \operatorname{SD}[n=3])^{\mathrm{a}}$} \\
\hline & & Second & Third \\
\hline \multicolumn{4}{|l|}{ T. aphylla } \\
\hline Uvalde, TX & 23 & $0.0 \pm 0.0 \mathrm{~g}$ & $0.0 \pm 0.0 \mathrm{e}$ \\
\hline Yuma, AZ & 18 & $38.9 \pm 25.5 \mathrm{~b}, \mathrm{c}, \mathrm{d}, \mathrm{e}$ & $38.9 \pm 25.5 b$ \\
\hline \multicolumn{4}{|l|}{ T. canariensis } \\
\hline Boca Chica, TX & 23 & $47.6 \pm 4.1 \mathrm{a}, \mathrm{b}, \mathrm{c}, \mathrm{d}$ & $39.3 \pm 12.9 b$ \\
\hline Galveston, TX & 22 & $31.0 \pm 18.0 \mathrm{c}, \mathrm{d}, \mathrm{e}, \mathrm{f}, \mathrm{g}$ & $14.3 \pm 14.3 \mathrm{~d}, \mathrm{e}$ \\
\hline Cameron Parish, LA & 20 & $15.1 \pm 14.4 \mathrm{e}, \mathrm{f}, \mathrm{g}$ & $4.8 \pm 8.2 \mathrm{e}$ \\
\hline Texas City, TX & 20 & $15.9 \pm 16.7 \mathrm{~d}, \mathrm{e}, \mathrm{f}, \mathrm{g}$ & $4.8 \pm 8.2 \mathrm{e}$ \\
\hline \multicolumn{4}{|c|}{ T. chinensis $\times T$. canariensis } \\
\hline Pecos River/I-10, TX & 23 & $8.3 \pm 14.4 \mathrm{f}, \mathrm{g}$ & $4.2 \pm 7.2 \mathrm{e}$ \\
\hline \multicolumn{4}{|l|}{ T. parviflora } \\
\hline Crawford, TX & 22 & $31.5 \pm 15.2 \mathrm{c}, \mathrm{d}, \mathrm{e}, \mathrm{f}$ & $9.5 \pm 16.5 \mathrm{~d}, \mathrm{e}$ \\
\hline \multicolumn{4}{|l|}{ T. ramosissima } \\
\hline Las Cruces, NM & 16 & $63.3 \pm 15.3 \mathrm{a}, \mathrm{b}$ & $43.3 \pm 20.8 b$ \\
\hline Lovell, WY & 20 & $75.4 \pm 15.9 \mathrm{a}$ & $70.6 \pm 13.1 \mathrm{a}$ \\
\hline Yuma, AZ & 22 & $50.6 \pm 18.2 \mathrm{a}, \mathrm{b}, \mathrm{c}$ & $31.5 \pm 15.1 \mathrm{~b}, \mathrm{c}, \mathrm{d}$ \\
\hline Total or mean & 229 & 34.3 & 23.7 \\
\hline
\end{tabular}

${ }^{a}$ Means within the same column followed with the same letter are not significantly different $(P<0.05$, Ryan-Einot-Gabriel-Welsch Multiple $F$ test; SAS Institute (1990)). Data were subjected to the arc sine square root transformation before analysis. Non-Tamarix species listed in Table 2 (Test L1) were included in analysis; all non-Tamarix values were zero). The three observations represent three cohorts of 4-8 first instar larvae.

reached the third instar, although several died during the prepupal and pupal stages on these plants. On Frankenia salina, only one larva of 12 reached the second instar (it produced an adult) and all larvae died as first instars on $F$. jamesii and $F$. johnstonii. All larvae died during the first instar on the other 12 test-plant species (Table 2).

\subsection{Larval host range: beetles from Kazakhstan}

Test L4, Temple - vial test, laboratory, June 2000, 21 test plants. Survival of Kazakhstan beetles from neonate larva to adult was high $(75-83 \%)$ on $T$. ramosissima from Pueblo, T. parviflora from Lovelock, and on $T$. chinensis from Artesia. Survival was somewhat lower on $T$. aphylla and significantly lower on $T$. canariensis from Texas City and on $T$. ramosissima from Lovell, and lowest on T. chinensis from Seymour. Eight of the 12 larvae reached the prepupal stage on $T$. canariensis and on $T$. ramosissima from Lovell, but several of these died during the prepupal stage. All larvae on the other 14 non-Tamarix plant species died during the 1st instar, including those on $F$. salina and $F$. johnstonii (Table 2).

3.4. Larval tests of additional habitat associates, Hali-
modendron and other legumes, and agricultural crops

We conducted two tests at Temple using legumes because of reports in the Russian literature of $D$. elongata damaging the woody legumes Halimodendron and Ammodendron in Kazakhstan and Uzbekistan (see Literature Records and Field Surveys in Asia, above). Another test at Albany was conducted to demonstrate to local growers that D. e. deserticola would not damage agricultural crops. All were no-choice tests conducted in sleeve bags over branches of potted plants, held in the laboratory or greenhouse, using Chinese beetles from Fukang.

Test L5, Temple - bag test, laboratory, August 2000, Halimodendron test. Neonate larvae bagged on $H$. halodendron did not feed or remain upon the plant and only crawled around on the sleeve-bags; all larvae died in the first instar. We also placed five early third-instar larvae in sleeve bags on a $H$. halodendron plant; these also did not feed and died either molting or in the pupal stage. Larvae caged on the control, $T$. ramosissima $\times T$. chinensis, fed on leaves and developed normally, with $59 \%$ reaching the adult stage (Tables 2 and 4 ).

Test L6, Temple - bag test, laboratory, August 2000, test on other legumes. We also conducted a no-choice larval test on five legumes: catclaw acacia, honey mesquite, mescalbean (all trees that are native to the southwest), alfalfa and soybean, with a $T$. ramosissima control. On the test plants, only one larva of 220 tested survived to the second instar (on mesquite) and all other larvae died during the first instar. We never observed feeding on the test plants and the larvae often were crawling on the sleeve bags. Larvae on the Tamarix control fed and developed normally, with $78 \%$ reaching the adult stage (Tables 2 and 4). 
Table 4

Survival of $D$. e. deserticola from Neonates to adults on Halimodendron and other Leguminous plants (Fabaceae): No-choice tests in sleeve bags on potted plants in the laboratory, Temple, Texas, August-September, 2000 ${ }^{\mathrm{a}}$

\begin{tabular}{|c|c|c|c|c|c|c|c|c|}
\hline \multirow[t]{3}{*}{ Plant species } & \multirow{3}{*}{$\begin{array}{l}\% \text { Survival to } \\
\text { adult }{ }^{\mathrm{b}}[\text { mean } \pm \mathrm{SD} \\
(\text { n) }(\text { range })]\end{array}$} & \multirow{3}{*}{$\begin{array}{l}\text { Mean stage } \\
\text { reached }^{\mathrm{c}} \\
{[\text { mean } \pm \mathrm{SD}(n)} \\
(\text { range })]\end{array}$} & \multicolumn{6}{|c|}{ Number (and \%) reaching stage } \\
\hline & & & \multicolumn{3}{|c|}{ Larval instar } & \multirow[b]{2}{*}{ Prepupa } & \multirow[b]{2}{*}{ Pupa } & \multirow[b]{2}{*}{ Adult } \\
\hline & & & First & Second & Third & & & \\
\hline \multicolumn{9}{|l|}{ Test L5 (Fukang, China beetles) } \\
\hline $\begin{array}{l}\text { Tamarix ramosissima } \times T \text {. chinensis, } \\
\text { Stillwater NWR, NV }\end{array}$ & $\begin{array}{l}59.0 \pm 31.4(10) \mathrm{a} \\
(0-100)\end{array}$ & $\begin{array}{l}5.2 \pm 1.7(51) \mathrm{a} \\
(1-6)\end{array}$ & $\begin{array}{l}51 \\
(100)\end{array}$ & $\begin{array}{l}42 \\
(82)\end{array}$ & $\begin{array}{l}40 \\
(78)\end{array}$ & $\begin{array}{l}35 \\
(67)\end{array}$ & $\begin{array}{l}34 \\
(67)\end{array}$ & $\begin{array}{l}30 \\
(59)\end{array}$ \\
\hline $\begin{array}{l}\text { Halimodendron halodendron (Pallas) } \\
\text { Voss (salt tree) }\end{array}$ & $\begin{array}{l}0.0 \pm 0.0(10) b \\
(0)\end{array}$ & $\begin{array}{l}1.0 \pm 0.1(50) b \\
(1)\end{array}$ & $\begin{array}{l}50 \\
(100)\end{array}$ & $\begin{array}{l}0 \\
(0)\end{array}$ & $\begin{array}{ll}0 \\
(0)\end{array}$ & $\begin{array}{ll}0 \\
(0)\end{array}$ & $\begin{array}{l}0 \\
(0)\end{array}$ & $\begin{array}{l}0 \\
(0)\end{array}$ \\
\hline \multicolumn{9}{|l|}{ Test L6 (Chilik, Kazakhstan beetles) } \\
\hline $\begin{array}{l}\text { T. chinensis, Bishop } \\
\text { (Poleta Canyon), CA }\end{array}$ & $\begin{array}{l}78.2 \pm 22.7(11) \text { a } \\
(20-100)\end{array}$ & $\begin{array}{l}5.2 \pm 1.7(55) \mathrm{a} \\
(1-6)\end{array}$ & $\begin{array}{l}55 \\
(100)\end{array}$ & $\begin{array}{l}49 \\
(89)\end{array}$ & $\begin{array}{l}49 \\
(89)\end{array}$ & $\begin{array}{l}45 \\
(82)\end{array}$ & $\begin{array}{l}45 \\
(82)\end{array}$ & $\begin{array}{l}43 \\
(78)\end{array}$ \\
\hline Prosopis glandulosa Torrey var. & $0.0 \pm 0.0(10) b$ & $1.0 \pm 0.1(50) b$ & 50 & 1 & 0 & 0 & 0 & 0 \\
\hline glandulosa (honey mesquite) & $(0)$ & $(1-2)$ & $(100)$ & (2) & (0) & (0) & $(0)$ & $(0)$ \\
\hline $\begin{array}{l}\text { Acacia greggii Gray } \\
\text { (catclaw acacia) }\end{array}$ & $\begin{array}{l}0.0 \pm 0.0(10) b \\
(0)\end{array}$ & $\begin{array}{l}1.0 \pm 0.0(50) b \\
(1)\end{array}$ & $\begin{array}{l}50 \\
(100)\end{array}$ & $\begin{array}{l}0 \\
(0)\end{array}$ & $\begin{array}{l}0 \\
(0)\end{array}$ & $\begin{array}{l}0 \\
(0)\end{array}$ & $\begin{array}{l}0 \\
(0)\end{array}$ & $\begin{array}{l}0 \\
(0)\end{array}$ \\
\hline $\begin{array}{l}\text { Sophora secundiflora (Ortega) Lag. Ex } \\
\text { DC (mescalbean) }\end{array}$ & $\begin{array}{l}0.0 \pm 0.0(10) b \\
(0)\end{array}$ & $\begin{array}{l}1.0 \pm 0.0(50) b \\
(1)\end{array}$ & $\begin{array}{l}50 \\
(100)\end{array}$ & $\begin{array}{l}0 \\
(0)\end{array}$ & $\begin{array}{l}0 \\
(0)\end{array}$ & $\begin{array}{l}0 \\
(0)\end{array}$ & $\begin{array}{l}0 \\
(0)\end{array}$ & $\begin{array}{l}0 \\
(0)\end{array}$ \\
\hline $\begin{array}{l}\text { Medicago sativa } \mathrm{L} \text {. } \\
\quad \text { (alfalfa) }\end{array}$ & $\begin{array}{l}0.0 \pm 0.0(10) b \\
(0)\end{array}$ & $\begin{array}{l}1.0 \pm 0.0(50) b \\
\text { (1) }\end{array}$ & $\begin{array}{l}50 \\
(100)\end{array}$ & $\begin{array}{l}0 \\
(0)\end{array}$ & $\begin{array}{l}0 \\
(0)\end{array}$ & $\begin{array}{l}0 \\
(0)\end{array}$ & $\begin{array}{l}0 \\
(0)\end{array}$ & $\begin{array}{l}0 \\
(0)\end{array}$ \\
\hline $\begin{array}{l}\text { Glycine max }(\mathrm{L} .) \text { Merrill } \\
\text { (soybean) }\end{array}$ & $\begin{array}{l}0.0 \pm 0.0(4) b \\
(0)\end{array}$ & $\begin{array}{l}1.0 \pm 0.0(20) b \\
(1)\end{array}$ & $\begin{array}{l}20 \\
(100)\end{array}$ & $\begin{array}{l}0 \\
(0)\end{array}$ & $\begin{array}{l}0 \\
(0)\end{array}$ & $\begin{array}{l}0 \\
(0)\end{array}$ & $\begin{array}{l}0 \\
(0)\end{array}$ & $\begin{array}{l}0 \\
(0)\end{array}$ \\
\hline
\end{tabular}

\footnotetext{
${ }^{a}$ Larvae held in groups of five in mesh bags among four potted plants of each plant species.
}

${ }^{\mathrm{b}}$ Sample size $(n)$ is number of mesh bags. Ranks of values followed by the same letter within the same column and test are not significantly different $(P<0.05$; Kruskal-Wallis Test on ranks using PROC GLM-LSMEANS test (SAS Institute, 1990)).

${ }^{\mathrm{c}}$ Stage reached: $1=$ first instar larva; $2=$ second instar larva; $3=$ third instar larva; $4=$ Prepupa; $5=$ Pupa; $6=$ Adult. Sample size $(n)$ is number of individual larvae. Means within the same column and test followed with the same letter are not significantly different $(P<0.05$, Fisher's Protected LSD Test; SAS Institute (1990); analysis of \% survival by grouped larvae)

Test L7, Albany — bag test, greenhouse, August 1999, nine agricultural crops. This test measured development of larvae on nine representative crop plants of importance in saltcedar-infested agricultural areas of California. On the control, T. parviflora $\times T$. gallica hybrid, $14.3 \%$ of the neonate larvae produced adults but all larvae died during the first instar on the nine crop plants (Table 2).

\subsection{Consensus of larval tests L2-L6}

Tamarix species. The combined data from larval tests L2-L4 and the controls in tests L5 and L6 (Table 2) provide an overall understanding of the relative value of the six species and two hybrids of the 18 accessions of Tamarix tested, although a statistical analysis cannot be performed because of the different conditions and different species and accessions included in each test. (We excluded the low values of accessions of $T$. chinensis from Cangzhou, China and Seymour, TX, and of the $T$. parviflora hybrid as probably being caused by poor plant quality.)

The greatest percentage of neonate larvae developing to the adult stage was on $T$. chinensis from China, Artesia, and Bishop (four test/accessions) with $68.3 \%$, (and $54.7 \%$ for the $T$. chinensis $\times T$. canariensis hybrid), and on T. austromongolica from China (but only one test/ accession) with $65.8 \%$. Next, in close succession, were $T$. aphylla (four test/accessions) with $54.8 \%, T$. parviflora (three test accessions) with $55.5 \%, T$. canariensis/T. gallica (three test/accessions) with $54.8 \%$, and T. ramosissima (seven test/accessions) with $53.6 \%$ (and with $59.0 \%$ for the $T$. ramosissima $\times T$. chinensis hybrid). Maximum survival percentages also are of interest in providing some insight into survival potential. Maximum values were $83.3 \%$ for $T$. ramosissima, $T$. parviflora, $T$. canariensis, and T. aphylla, $78.2 \%$ for $T$. chinensis, and $65.8 \%$ for $T$. austromongolica. Both mean values and maximum values indicate that all six $T a$ marix species tested in these five larval tests are about equally suitable for larval development of $D$. e. deserticola. Our data do not indicate that the lower-ranked Tamarix species are not also good hosts, since these had the greatest maximum survival rate.

Frankenia species. These were included in four tests. The 191 larvae tested produced three adults, two of which were deformed, or $1.6 \%$ of all neonates tested, or $1.7 \%$ if Test 1 is excluded (Table 2); the rest of the neonates all died in the first instar. Subsequent tests at Albany revealed greater survival rates and so additional testing was initiated to insure safety (see Lewis et al., 2003a). 
Habitat associates and agricultural crops. At Temple and Albany, we tested 321 neonate larvae on 12 habitat associates (Salix, Populus, Baccharis, Prosopis, Acacia, Sophora, and Halimondendron) and 189 larvae on 12 agricultural crops. All larvae died in the first instar.

Other non-Tamaricales species. Test L1 provided inconclusive results, probably because our testing procedure was not yet well developed; it contained the greatest number of test plants with 40 species and accessions. Larvae exhibited a strong tendency for partial development on all the Tamarix accessions and no tendency to develop (all died during the first instar) on the other 29 species tested. Survival to the second and third instar, respectively, on the $11 \mathrm{Ta}$ marix species and accessions in Test L1 (Table 2), are given in Table 3. Fourteen of these non-Tamaricales species were included in other tests with similar results: all neonate larvae died during the first instar (Table 2).

\subsection{Adult host range}

We conducted five multiple-choice and two no-choice tests on a wide range of plant species and Tamarix accessions from 1992 to 2001 at Temple, and in China and Kazakhstan, to determine host selection by adults of $D$. $e$. deserticola based on their behaviors of alighting and resting, feeding, and oviposition.

Test A1, Temple - small cages, laboratory, July 1992, 10 test plants, presence, feeding, and oviposition, multiplechoice, beetles from Turpan, 16-h photoperiod. Significantly more adults (17.0-27.7\% of the total) were present on the two accessions of $T$. ramosissima, an accession of $T$. chinensis, and on T. aphylla as compared to the $4.4-6.3 \%$ observed on the three other Tamarix species, and the $0-0.6 \%$ of the total on the three nonTamarix species (Table 5). Feeding, based on the amount of frass under each plant, was significantly greater (30 and $32 \%$ of the total) on T. ramosissima from Las Cruces and Lovell than on the other Tamarix plants, and no frass was collected from under the three non-Tamarix plants. Females laid from 12 to $29 \%$ of all eggs on T. ramosissima and a Chinese Tamarix sp., 17\% on $T$. aphylla, and less than $10 \%$ on any other test plants. The 10 eggs laid on Amorexia and 7 on Bixa (one egg mass each) (Table 5), was not surprising, since they sometimes also oviposited on the cage walls in other tests. This test provided consistent data on the number of adults attracted to and feeding on host versus nonhost plants, but provided less discriminating data for oviposition. This was the only test we did that measured feeding (by weighing the frass under each plant), which provided very discriminating data. However, the measurement of frass in small cages could not be done reliably in larger cages under more natural conditions, and was not repeated.
Test A2, Temple-medium cages, greenhouse, August 1993, 20 test plants, presence, feeding, and oviposition, multiple-choice, beetles from between Turpan and Urumqi, natural photoperiod. This large test failed because few active adults were observed and the 600 adults laid only 26 eggs during the 14 days of the test. A likely cause of failure was the short daylength under the natural photoperiod in the greenhouse during the August test period; this may have triggered diapause. The remainder of this culture continued ovipositing in the quarantine facility (16-h photoperiod), and at about the same rate as before they were shipped from Beijing (see discussion of diapause by Lewis et al., 2003b).

Tests A3-A5, China-medium cages, outdoor and laboratory, August 1995, 11 test plants, oviposition, multiple-choice, beetles from Fukang. We conducted three multiple-choice tests of ovipositional host-plant selection in China in 1995, one at Beijing and two at Hohhot. These tests compared beetle response to three US accessions of T. ramosissima, three US accessions of $T$. chinensis and two of $T$. aphylla, with that of two Chinese species of Tamarix and of Myricaria. The results were highly variable between replications in the cages, probably because of differences in plant quality or the position of the plants. Nevertheless, females laid 18 71 eggs per replication on each of the five best US and one Chinese accessions of $T$. chinensis and $T$. ramosissima, fewer on the Chinese Myricaria, and less than eight eggs per replication on athel and two other Tamarix plants (Table 6).

Test A6, Temple - small cages, laboratory, 21 August 2000, Halimodendron, no choice, Fukang beetles, 16- $h$ photoperiod. During this test the beetles always were observed on the screen walls of the cage and never on the plants, and they apparently never fed. Nine beetles survived 2 days, four for 4 days, and all 10 were dead by the fifth day; they laid no eggs.

Two tests in Kazakhstan of erroneously reported hosts-no-choice bag test, Halimodendron and Ammodendron, April-June 2001. On H. halodendron, the 220 adults and 87 eggs tested in the field at Buryndysu, and 96 adults, 70 first-, 30 second- and 103 third-instars tested on the laboratory grounds at Almaty, all starved within 6 days. The only feeding was of small bites on five young leaves and two older leaves with small damage. On $A$. bifolium, the 72 adults and 62 eggs placed on one plant at the laboratory grounds all starved within 5 days, with no feeding on the plant. We conclude from this test in Kazakhstan, and from Tests L5 and A6 at Temple, that D. e. deserticola is unable to feed, develop or oviposit on the Central Asian shrubs $H$. halodendron or A. bifolium. These appear not to be host plants, and the literature records on these plants by Yakhontov and Davletshina (1959) and by Sinadsky $(1960,1968)$ are erroneous, caused by a misidentifica- 
Table 5

Adult alighting behavior, feeding, and oviposition of the leaf beetle, D. e. deserticola, on excised leaf bouquets of various plants in a multiple-choice experiment in the quarantine laboratory at Temple, TX, July $1992($ Test A1)

\begin{tabular}{|c|c|c|c|c|c|c|}
\hline \multirow[t]{2}{*}{ Plant species } & \multicolumn{2}{|c|}{ Adults observed on bouquets } & \multicolumn{2}{|c|}{ Frass deposited below bouquets } & \multicolumn{2}{|l|}{ Eggs laid on bouquets $\%$} \\
\hline & $\begin{array}{l}\% \text { total for test } \pm \mathrm{SD} \\
\text { (range) } \\
\text { (six replicates) }\end{array}$ & Total No. & $\begin{array}{l}\% \text { total for test } \pm \mathrm{SD} \\
\text { (range) } \\
\text { (five replicates) }\end{array}$ & Total (mg) & $\begin{array}{l}\% \text { total for test } \pm \mathrm{SD} \\
\text { (range) } \\
\text { (six replicates) }\end{array}$ & Total No. \\
\hline $\begin{array}{l}\text { Tamarix ramosissima } \\
\text { Las Cruces, NM }\end{array}$ & $21.3 \pm 8.4(12-34) \mathrm{a}$ & 35 & $32.2 \pm 8.5(20-41) \mathrm{a}$ & 68.6 & $12.4 \pm 15.9(0-34) \mathrm{abc}$ & 51 \\
\hline T. ramosissima Lovell, WY & $27.7 \pm 18.6(10-60) \mathrm{a}$ & 43 & $29.7 \pm 8.1(21-39) \mathrm{a}$ & 62.7 & $19.0 \pm 20.2(0-51) \mathrm{ab}$ & 87 \\
\hline T. aphylla Uvalde, TX & $17.0 \pm 8.0(4-25) \mathrm{a}$ & 25 & $13.5 \pm 7.1(7-25) b$ & 24.9 & $16.9 \pm 12.5(0-32) a b$ & 70 \\
\hline $\begin{array}{l}\text { T. canariensis } \times T \text {. chinensis } \\
\text { and/or } T \text {. chinensis } \text { Pecos River } \\
\text { at I- } 10 \text {, TX }\end{array}$ & $17.4 \pm 10.4(4-29) \mathrm{a}$ & 26 & $11.3 \pm 8.3(1-23) b$ & 24.3 & $9.5 \pm 10.6(0-21) \mathrm{abc}$ & 41 \\
\hline Tamarix sp. Turpan, China & $5.3 \pm 5.0(0-12) b c$ & 7 & $6.5 \pm 3.3(4-12) b c$ & 12.1 & $28.8 \pm 37.8(0-100) \mathrm{a}$ & 52 \\
\hline $\begin{array}{l}\text { T. canariensis Cameron } \\
\text { Parish, LA }\end{array}$ & $4.4 \pm 4.6(11-27) b c$ & 7 & $3.8 \pm 3.7(0-8) \mathrm{c}$ & 8.6 & $4.7 \pm 8.1(0-20) b c$ & 20 \\
\hline T. parviflora Crawford, TX & $6.3 \pm 5.5(0-16) b$ & 11 & $3.0 \pm 4.1(0-8) \mathrm{cd}$ & 9.7 & $4.8 \pm 6.2(0-14) b c$ & 19 \\
\hline Fouquieria splendens & $0.6 \pm 1.4(0-4) b c$ & 1 & $0.0 \pm 0.0(0-0) \mathrm{d}$ & 0 & $0.0 \pm 0.0(0-0) b c$ & 0 \\
\hline Amoreuxia wrightii & $0.0 \pm 0.0(0-0) b c$ & 0 & $0.0 \pm 0.0(0-0) \mathrm{d}$ & 0 & $2.3 \pm 5.7(0-14) \mathrm{c}$ & 10 \\
\hline Bixa orellana & $0.0 \pm 0.0(0-0) b c$ & 0 & $0.0 \pm 0.0(0-0) \mathrm{d}$ & 0 & $1.6 \pm 4.0(0-10) \mathrm{c}$ & 7 \\
\hline
\end{tabular}

${ }^{\mathrm{a}}$ Each of six cages (replications) contained 30 unsexed adults, with two bouquets of each test plant, adults on plants counted daily for 2 days, frass and eggs measured after 2 days. Means within the same column followed by the same letter are not significantly different $(P<0.05$, Fisher's Protected LSD Test; SAS Institute (1990)). Percentage data were subjected to the arc-sine square-root transformation prior to analysis. 
Table 6

Ovipositional host-plant selection by D. e. deserticola: multiple-choice tests, Beijing and Hohhot, China, August $1995^{\text {a }}$

\begin{tabular}{|c|c|c|c|c|c|c|c|c|}
\hline \multirow[t]{4}{*}{ Test plant } & \multicolumn{8}{|c|}{ No. of eggs laid on plants } \\
\hline & \multirow{2}{*}{\multicolumn{2}{|c|}{$\begin{array}{l}\text { Beijing } \\
\text { Garden } \\
\text { Test A3 }\end{array}$}} & \multicolumn{4}{|c|}{ Hohhot } & \multirow[t]{3}{*}{ Total } & \multirow{3}{*}{$\begin{array}{l}\text { Mean no. } \\
\text { per rep }\end{array}$} \\
\hline & & & \multicolumn{2}{|c|}{$\begin{array}{l}\text { Laboratory } \\
\text { Test A4 }\end{array}$} & \multirow{2}{*}{$\begin{array}{l}\text { Garden } \\
\text { Test A5 } \\
\text { Rep } 1\end{array}$} & \multirow[b]{2}{*}{ Rep 2} & & \\
\hline & Rep 1 & Rep 2 & Rep 1 & Rep 2 & & & & \\
\hline \multicolumn{9}{|l|}{ Tamarix chinensis } \\
\hline $\begin{array}{l}\text { Cedar Bluff, KS (AY090386) } \\
\text { (ex. T. ramosissima) }^{\mathrm{b}}\end{array}$ & 6 & 136 & & & & & 142 & 71.0 \\
\hline $\begin{array}{l}\text { Artesia, NM (AY090386) } \\
(\text { ex. T. ramosissima) }\end{array}$ & 129 & 41 & 10 & 12 & 13 & 16 & 221 & 36.8 \\
\hline Seymour, TX & 16 & 28 & 58 & 7 & 0 & 12 & 121 & 20.1 \\
\hline Beijing Tianjin, China & 15 & 22 & & & & & 37 & 18.5 \\
\hline \multicolumn{9}{|l|}{ T. ramosissima } \\
\hline Lovell, WY & 5 & 0 & 87 & 0 & 29 & 26 & 147 & 24.5 \\
\hline Bear Creek, CA & 14 & 21 & & & & & 35 & 17.5 \\
\hline Las Cruces, NM & 2 & 2 & & & & & 4 & 2.0 \\
\hline \multicolumn{9}{|l|}{ T. aphylla } \\
\hline Litchfield, AZ & 25 & 0 & 0 & 0 & 4 & 16 & 45 & 7.5 \\
\hline Uvalde, TX & 9 & 26 & 0 & 0 & 0 & 0 & 35 & 5.8 \\
\hline T. austromongolica & & & 0 & 0 & 0 & 2 & 2 & 0.5 \\
\hline Myricaria sp. & & & 0 & 9 & 24 & 19 & 52 & 13.0 \\
\hline Total eggs & 221 & 276 & 155 & 28 & 70 & 91 & 841 & \\
\hline Adults in cage & 100 & 100 & 100 & 100 & \multirow{2}{*}{\multicolumn{2}{|c|}{$\begin{array}{c}274 \\
0.255\end{array}$}} & 674 & \\
\hline Eggs/adult & 2.21 & 2.76 & 1.55 & 0.28 & & & & \\
\hline
\end{tabular}

${ }^{\mathrm{a}}$ These tests were conducted by our cooperators Xi Liang Jiang and Qing Guang Lu at Beijing, and by Xi Liang Jiang, Ai Peng Liu, and Jian Feng Wang at Hohhot. Tests began 16 August at Beijing, 18 August at Hohhot. Eggs counted after 1 week.

${ }^{\mathrm{b}}$ Previously identified as T. ramosissima by both B.R. Baum and W.L. Crins, but J.F. Gaskin identified specimens from our plant cultures where the GenBank Accession No. of the haplotype of the nuclear pepC gene is given. 
tion of the beetles, as proposed by Lopatin (letter, 1 September 2000).

\section{General discussion}

\subsection{Host specificity of D. e. deserticola}

We measured the host specificity of $D$. e. deserticola using 3547 larvae and 1852 adults to test their survival, development and selection of 84 plant species and accessions in 14 laboratory or field-cage tests over a 10 year period. For larvae, we tested 79 plant species and accessions: five accessions of $T$. ramosissima and one hybrid, four accessions of $T$. chinensis and one hybrid, two accessions of $T$. canariensis and two of $T$. canariensis or $T$. gallica (uncertain identification), three accessions of $T$. parviflora and one hybrid, two accessions of $T$. aphylla, one accession of $T$. austromongolica, one species of Myricaria, and three species and four accessions of Frankenia. We also tested 11 other species in seven other families of the subclass Caryophyllidae (including three agricultural or horticultural species and three habitat associates) and 33 species in 17 families of subclasses Rosidae and Asteridae (including 15 species of agricultural or horticultural importance and 10 species of habitat associates), and eight other agricultural crops. For adults, we tested 12 plant species and 20 accessions: six species of Tamarix and one hybrid, one species of Myricaria, four species of Rosidae (including Halimondendron and Ammodendron in the Fabaceae), and one species of Asteridae.

The large number of Tamarix accessions we tested was necessary because of the uncertain identification of species in the field and because taxonomic concepts of higher categories changed during the testing program (see previous discussion in Section 1: Evaluation, World Distribution, and Taxonomy, and Section 2: Plants-Selection of Species). To insure that variability in the field would be represented, we took Tamarix test plants from stands in several different areas. In 1993 and 1995, all our samples from major western infestations were identified as $T$. ramosissima by both recognized Tamarix taxonomists, Drs. Bernard Baum (Agriculture Canada, Ottawa, Ont.) and William Crins (Duke University, Durham, NC). They also identified $T$. parviflora from Texas, and T. canariensis from along the Texas and Louisiana coasts. These were placed in the order Violales, subclass Dilleniidae, as defined by Cronquist (1981, 1988) so we tested species from several of the more closely related families of that order. Spichiger and Savolainen (1997) placed the Tamaricaceae back into the order Tamaricales, as earlier taxonomists also had done, and in the subclass Caryophyllidae. Therefore, we added test plants from several families and orders of that subclass that now were more closely related to Tamarix.
However, during our investigations John Gaskin (Missouri Botanical Gardens, St. Louis, Missouri) was conducting a several-year DNA analysis of Tamarix he collected from many locations both in the United States and in the Old World. He determined that the T. $r a$ mosissima from several of our plant collection sites actually consisted of varying mixtures of $T$. ramosissima, T. chinensis, $T$. canariensis, $T$. parviflora, and maybe $T$. gallica, or hybrids of these, and with various genotypes of each species (Gaskin and Schaal, 2002), which identifications we have used here.

Our tests predict that, after release into nature in the United States, D. e. deserticola will be host specific to species of the genus Tamarix. Both larval and adult host-specificity tests demonstrated that the beetles strongly preferred and larvae developed better on species of Tamarix but with substantial variability between Tamarix species and accessions and between tests. In seven tests using 79 test-plant species and accessions, development from neonate larvae to adults occurred only on 21 of the 22 species and accessions of Tamarix, and with up to $78-83 \%$ survival on several accessions. A few also developed to adults on Myricaria, (also in family Tamaricaceae), and on the three species of Frankenia but all larvae died during the first instar on all the other 53 species tested. The low survival rate on Frankenia indicated that these were poor larval hosts (Tables 2 and 4). However, Lewis et al. (2003a) found Frankenia spp. to be moderately satisfactory as larval hosts, though not as good as Tamarix.

A phenomenon that was made clear by Tests L1 and L2 was that even if adults were not produced, larvae developed further on the better hosts, but on non-hosts they died during the first instar. Thus, even though no adults were produced on several Tamarix accessions in Test L1, they appeared to be host plants because of larval development. We speculate that two distinct hostrange criteria operate: the non-host plants do not produce the stimulus to initiate larval feeding, while the poor hosts stimulate the feeding response but are lacking in some nutritional factor that causes the beetles to die in the later stages, especially while molting to the pupal or adult stages.

A true host plant must allow an insect to complete its entire life cycle, and in sufficient numbers to sustain a positive rate of increase. The host range of an insect depends on several stimuli and nutritional criteria. Zwölfer and Harris (1971) categorized these as hostplant finding, host-plant acceptance for feeding and oviposition, and host-plant suitability for development and reproduction. All of these involve the insect's response to specific chemical, visual, or tactile stimuli, and the last two also involve nutritional or toxic qualities, or feeding deterrents of the plant. Overall success is the product of success in each stage. Any one of these five stages can act as the limiting factor in 
determining host specificity. Testing of the insect life stage that actually performs the host selection in nature is important. D. e. deserticola is highly host specific to saltcedar during two of the phases of host selection (host-plant finding, and host-plant acceptance for oviposition and adult feeding) but is only moderately host specific during the third phase (host-plant suitability for larval development).

The life plan of $D$. e. deserticola, with a pattern of greater range of host-plant suitability for larval development and smaller host range for adults, probably is advantageous for this insect. The mobile adults should be highly host selective to find the plants on which the larvae can best develop. The larvae can crawl short distances but appear not to be windblown and have only limited mechanisms for dispersal or host selection, mostly living or dying on the plants where the eggs were laid. The slightly broader host range of larvae better ensures their ability to produce adults that then can find the best hosts in the next generation.

Our adult tests also indicated a strong preference of adults for alighting, feeding, and oviposition on the saltcedar test plants, less on athel and Myricaria, and no response to the other plants tested. In other tests conducted in large outdoor cages at Temple in 2000, Lewis et al. (2003a) found that adults do not recognize Frankenia spp. as hosts and thus rarely oviposit on them. They found that adults strongly preferred Tamarix for alighting/resting/feeding: $99.6 \%$ of the total on the three species of Tamarix and only $0.4 \%$ resting on the three species of Frankenia tested. Females laid $98.9 \%$ of their eggs on the three species of Tamarix, only $1.1 \%$ on $F$. jamesii, and none on the other Frankenia species (Lewis et al., 2003a).

Host range of $D$. e. deserticola larvae from southeastern Kazakhstan (Test L4) was not different from larvae originating in western China; tests of adults conducted at Temple by Lewis et al. (2003a) confirmed this. Though the Kazakhstan beetles are separated from the Chinese by the ecological barrier of the 3000- to 5000-m high Tien Shan Mountains, beetles from both areas were identified as $D$. e. deserticola by Prof. I.K. Lopatin. Likewise, we found no differnces between beetles originating from Turpan (Tests L1 and A1) or between Turpan and Urumqi, China (Test L2) and beetles originating from Fukang, China (all other tests). Therefore, we found no evidence for distinct strains with different host ranges, which indicates that beetles from all four locations are equally safe to release in the United States.

Based on the results herein and those of Lewis et al. (2003a), we conclude that all of the deciduous saltcedars we tested (except for the $T$. parviflora $\times T$. gallica hybrid) are good hosts for $D$. e. deserticola, that Myricaria and T. aphylla (athel) are poor hosts, that Frankenia spp. also are poor hosts and probably are non-hosts under open-field conditions, and that all other plants tested are non-hosts.

\subsection{Differences between tests}

Results at Temple varied between different tests. In larval Test L1, survival of neonates to the adult stage was less than in later tests on the same host plants, and often occurred after the second or third instar. Nevertheless, we believe the comparisons between plants within this test are valid. The reasons for the low survival rate are not clear, but Test L1 was conducted in mid-summer when plant quality may have been low; however, survival was high in other tests still later in the season (Test L2). Also, this was our first test, and handling and testing procedures were not developed as well as in later tests. Too much or too little moisture in the vials caused some mortality but this was not biased toward any particular plant species that we tested.

In addition, the ranking of Tamarix plants in the various larval tests varied considerably. For example, $T$. aphylla (Yuma) ranked first in Test L3 and ninth in Test L2; we can only attribute this to plant quality. We always selected healthy looking foliage for testing and any differences in quality were not visually apparent. However, in the life-cycle test (Lewis et al., 2003b), significantly more larvae developed to the adult stage on young foliage $(91 \%)$ than on old foliage $(64 \%)$ of the same accession. Differences in root environment (soil and/or fertilization) or other outdoor factors may have affected survival. Tests conducted at Temple in 1996 using larvae of Coniatus tamarisci (F.) (Coleoptera: Curculionidae) on saltcedar revealed that plants that had been fertilized supported a higher percentage of larvae surviving to the adult stage (DeLoach, unpublished data).

\subsection{Coevolution of Tamarix and its insects}

Kovalev (1995) stated that ancient, dominant plant species inevitably evolve communities of restricted oligophagous insect herbivores, which are retained across geologic time. Such specialized phytophages are characterized by increased host specificity during their evolution. He analyzed over 400 insects of the world fauna that inhabit the Tamaricaceae and concluded that some 325 species of insects and mites from 88 genera and 33 families, all classified as oligophages, were restricted to Tamarix, with some insects also attacking Myricaria and Reaumuria, but all in the family Tamaricaceae. He recommended more than 50 species as especially highly specific and most suitable for introduction for biological control.

Kovalev (1995) concluded that most insect phytophages of $T$. ramosissima also had evolved in the cold deserts north of the January isotherm $+8^{\circ} \mathrm{C}$ and did not attack Tamarix species south of that isotherm. He therefore stated that the "Introduction of specific phytophages collected from the regions dominated by $T$. 
ramosissima is safe for T. aphylla in the USA." He also stated that Tamarix insects from south of the January isotherm $+8{ }^{\circ} \mathrm{C}$ would be likely to attack $T$. aphylla and unlikely to attack $T$. ramosissima.

In general, we recognize the role of co-evolution in influencing the host range of insects and Kovalev's contribution provides valuable guidelines in the assessment of the many Tamarix phytophages and on the apparent immutability of high host-specificity in the history of introduced insects of other biological control of weeds projects. However, we distrust a complete reliance on this concept and believe host-range testing still is essential to demonstrate safety. Also, reasoning from a general concept to a specific insect species is risky because of the lack of information on behavior of many potential insect control agents. Some of our research indicates possible contradictions to Kovalev's co-evolutionary generalization. For example, D. e. deserticola from Tamarix in central Asia did attack T. aphylla in our tests, though it may not in nature. Also, the mealybug, Trabutina mannipara (Hemprich and Ehrenberg) (Homoptera: Pseudococcidae) from the Dead Sea of Israel (warmer than January isotherm $+8^{\circ} \mathrm{C}$ ), performed better on $T$. ramosissima than on $T$. aphylla (DeLoach, unpublished data), though its natural host is neither of these species.

\subsection{Risk to non-target plants after release of D. elongata}

The increased testing and regulatory protocols we have followed in the saltcedar program make non-target attack on native plants highly unlikely. This program has included the most extensive risk analysis and one of the most extensive testing programs of candidate control agents yet undertaken. DeLoach (1991), DeLoach and Tracy (1997), DeLoach et al. (2000), and Dudley et al. (2000) analyzed the environmental issues and concluded that the benefits from biological control of saltcedar far outweighed any probable negative effects, and that many declining plant and animal species (including probably 30 threatened or endangered species) would be benefited and none would be harmed. DeLoach and Tracy (1997) and DeLoach et al. (2000) further concluded that biological control was not likely to adversely affect the endangered southwestern willow flycatcher, with which the USDI Fish and Wildlife Service concurred (letter from USDI-FWS, 3 June 1999).

Two non-target plant taxa were of concern in our testing program: T. aphylla and the North American species of the genus Frankenia. Our testing program examined both these taxa extensively. The results indicate that athel will be fed on by $D$. e. deserticola but it is not a preferred host and it likely will incur less feeding pressure from this insect than will the saltcedars. Frankenia spp. are poor hosts and are unlikely to be damaged (see also, Lewis et al., 2003a).
We do not suggest that the risk of releasing $D . e$. deserticola for control of saltcedar is zero. However, to hold a requirement of zero risk is unrealistic and actually may be harmful to the ecosystems we are attempting to improve. This would end the use of biological control altogether and force reliance on other much more harmful and expensive control procedures. The minute risk of damage that might be produced by biological control must be weighed against the great known damage caused by saltcedars, and the risk from the no-action option of allowing this damage to continue, as pointed out by Pimentel et al. (1992) and Pimentel (2000). These dangers are revealed by surveys in Australia showing that more than 50 plant species are endangered because exotic, invading weeds out-compete them (Bell, 1983) and in Germany showing that 89 of 581 rare plants are declining because of herbicidal applications to control weeds (Sukopp and Trautmann, 1981). In the United States, Stein and Flack (1996) estimated that approximately 400 of the 972 federally listed threatened and endangered species of plants and animals are at risk primarily because of competition with and predation by non-native species. Wilcove et al. (1998) estimated that $48 \%$ of 56 imperiled birds and $30 \%$ of 641 species of plants in the continental United States are imperiled because of alien species. Recent programs along the Pecos River of New Mexico and Texas seek to eliminate extensive, monotypic stands of saltcedar, using herbicidal and mechanical controls. Although probably safe along the saline Pecos River, such controls are likely to damage native plant and animal communities if extended to other areas of mixed saltcedar-native vegetation unless biological control is incorporated. If biological control is not initiated, or is not successful, more of this type of control, and its accompanying ecosystem damage, may be expected.

\subsection{Expected results after release}

DeLoach and Tracy (1997) and DeLoach et al. (2000) predicted that the release of $D$. e. deserticola into nature will produce a gradual reduction in the size of plants and in foliage cover and density of saltcedar stands. This will allow a corresponding gradual increase in native plants and the eventual recovery of wildlife populations, at least in the majority of areas where water is available and soil salinity is not too great. Saltcedar is a very resilient plant, with large food reserves; it is known to resprout and regrow rapidly after the above-ground biomass is removed or killed, so control will not be rapid. Nevertheless, D. e. deserticola may have from three or four generations in the more southern areas to two generations in the more northern areas (Lewis et al., 2003b) so defoliation can occur several times during a growing season, increasing the annual stress on these trees. Also, the preference of D. e. deserticola for young 
foliage indicates that it may severely damage young plants, possibly killing them in one season. If saltcedar populations become so low and/or plant size so small that beetle populations greatly decline, saltcedar stands may resprout, grow larger, and increase in density until the beetles increase again. Recovery of dense native vegetation, together with continued attacks by the beetles, may maintain saltcedar density and canopy cover at very low levels.

We and our cooperators in Kazakhstan, Turkmenistan, and China have recorded several instances of severe defoliation of saltcedar stands by D. e. deserticola (Figs. 1 and 2). Mityaev and Jashenko (2001), during the 2001 field season in Kazakhstan, provided the first good documentation of control by D. e. deserticola in the field. In a large stand of $T$. ramosissima near Chilik, $120 \mathrm{~km}$ ENE of Almaty, they recorded beetle populations from their first appearance in the spring and until they reached several hundred per plant, and the resulting extensive dieback of all and death of some plants. The surviving plants resprouted from the base or from still living branches, but with a substantial overall reduction in size of the plants and in canopy cover of the stand (Fig. 2).

Some workers have questioned whether or not a defoliating insect is capable of controlling a tree such as saltcedar. Historically some of the most successful biological control agents for other weeds have been defoliators (Julien and Griffiths, 1999). Examples are other leaf beetles such as Chrysolina quadrigemina (Rossi) (Coleoptera: Chrysomelidae) that controlled St. Johnswort (Hypericum perforatum L.) in California and neighboring states (Huffaker and Kennett, 1959) and two species of Galerucella that presently are controlling purple loosestrife (Lythrum salicaria L.) at several locations (Blossey et al., 2001). The exotic elm leaf beetle, Xanthogaleruca luteola (Müller) (Coleoptera: Chrysomelidae), severely damages elm trees in the West (Luck and Schriven, 1976). In South Africa, an exotic, invading small riparian tree, Sesbania punicea (Cavanilles) Bentham, an ecological analog of saltcedar, was controlled by introducing three insect species from its site of origin in southern South America, a defoliating weevil, a seed feeder, and a stem borer; the native willows revegetated naturally and rapidly after control (Hoffmann and Moran, 1998). Several exotic, invasive insect species have proven their ability to seriously reduce the abundance of several native North American trees, which is equivalent to biological control except that the control was unplanned and unwanted. These cases illustrate the potential both of defoliating insects and of saltcedar to be controlled. The elm and loosestrife leaf beetles are closely related to Diorhabda. Preliminary unpublished data from releases of $D$. e. deserticola into field cages by us and our cooperators in six states indicate that this beetle caused substantial die-back and even death of some plants after only one year in the cages (Fig. 4).
We do not expect $D$. e. deserticola to be equally effective in all climatic zones now infested by saltcedar, and it may be attacked more by predators or parasites in some areas than in others. We expect that the introduction of additional control agents will be required to achieve the goal of $75-85 \%$ control of saltcedar. However, D. e. deserticola appears to be the most effective control agent we have investigated so far; it severely damages stands of Tamarix in Asia, and we believe it will have a major effect on reducing saltcedar stands in the United States. The beetles were released from the cages into the open field at eight sites in Texas, Colorado, Wyoming, Utah, Nevada, and California in May 2001 and their establishment and affects on saltcedar are now becoming apparent.

\section{Acknowledgments}

We express our sincere appreciation and indebtedness to the many workers who contributed to this research. Our overseas cooperators were essential to the collection and shipment of the test insects and for their great knowledge and experience of insect herbivores of $\mathrm{Ta}$ marix in its area of natural distribution. These were: Prof. Dr. Ivan Mityaev, who has worked with Tamarix insects in Kazakhstan since 1958, and Dr. Roman Jashenko, both with the Tethys Scientific Society, Laboratory of Entomology, Institute of Zoology, Kazakhstan Academy of Sciences, Almaty, who conduct cooperative research with us in Kazakhstan on the biology and field host range of D. elongata; Drs. Ren Wang and Qing Guang Lu, former directors of the Sino American Biological Control Laboratory (SABCL), Chinese Academy of Agricultural Sciences (CAAS), Beijing, who organized and assisted in the explorations for natural enemies in China, and Mr. Xi Liang Jiang of the SABCL who conducted the host-range testing at Beijing and Hohhot; Jeng Feng Wang and Aiping Liu of the Grassland Research Institute CAAS, Hohhot, Inner Mongolia, China, who conducted the host range testing there, and to Hong Yen Chen, present Director of SABCL for coordination and assistance in many aspects of the research in China; and Prof. Dr. Baoping Li (Department of Entomology, Nanjing Agricultural University, Nanjing, China) who assisted in the insect surveys and collected and shipped beetles to Temple and Albany. We thank Dr. Ren Wang, Dr. Baoping Li, and Prof. Ming Ting Lui (Academia Sinica, Urumqi) and Dr. Bob Pemberton (Aquatic Weed Control Research, USDA-ARS, Ft. Lauderdale, FL), who, on a survey trip in northwestern China in 1991, first suggested Diorhabda elongata as a control agent because of the great damage done to plantations of Tamarix. We also thank Prof. Lui for locating populations of the beetles, for field identification of the Tamarix species we encountered, and for 
assisting in the insect surveys. We thank Prof. Dr. Svetlana Myartseva, National Institute of Deserts, Flora and Fauna, Ministry of Nature Protection of Turkmenistan, Ashgabat, for field collections and preliminary testing in Turkmenistan; and Drs. Rouhollah Sobhian and Alan Kirk of the USDA/ARS European Biological Control Laboratory, Montpellier, France for surveys of host plants in Tunisia. We also thank Dr. Alexander Konstantinov of the ARS Systematic Entomology Laboratory, Beltsville, MD and Prof. I.K. Lopatin, Byelorussian University, Minsk, Belarus for identifying the Diorhabda specimens; Dr. T.J. Poprawski (now deceased), ARS Weslaco, Texas for examining overseas shipments for pathogens; Debra Eberts, Ecological Research and Investigations Group, USDI, Bureau of Reclamation, Denver, Colorado for supplying insects from her nursery cages; Drs. Bernard R. Baum, Agriculture Canada, Ottawa, Ont. and William L. Crins, Duke University, Durham, NC, for identifying the Tamarix specimens; Dr. John F. Gaskin, Missouri Botanical Gardens, St. Louis, Missouri, for DNA analysis of Tamarix species; and Dr. Dan Bean, Exotic and Invasive Weed Research, Western Regional Research Center, USDA-ARS, Albany, California for his review and discussion about the effects of photoperiod and temperature on diapause of D.e. deserticola. We express our appreciation to Tom Robbins at Temple for assistance with the experiments and cultures of plants and beetles. We thank Mrs. Patricia Sullivan for proofing the grammar in this and the following two papers in this series. We appreciate the substantial supplemental funding from the USDI Bureau of Reclamation over a period of several years and also from the USDI Bureau of Land Management and the USDAAPHIS Biological Control Institute, all of which was of great assistance in carrying out these investivations, especially at the overseas locations.

\section{References}

Anderson, B.W., Ohmart, R.D., 1984. Vegetation Management Study for the Enhancement of Wildlife Along the Lower Colorado River. Bureau Reclamation, Lower Colorado Region, Boulder City, NV, $529 \mathrm{p}$.

Anonymous, 1995. Encyclopedia of US Endangered Species. Zane Publishing, Dallas, Texas (CD).

Bao, P., 1989. Occurrence pattern of Diorhabda elongata deserticola Chen and its control in Erjina county. J. Pratacultural Sci. 6, 45-47 (in Chinese).

Baum, B.R., 1967. Introduced and naturalized tamarisks in the United States and Canada (Tamaricaceae). Baileya 15, 19-25.

Baum, B.R., 1978. The Genus Tamarix. Israel Academy of Sciences and Humanities, Jerusalem.

Bell, A., 1983. Native plants facing extinction. Ecosystems 37, 21-26.

Berti, N., Rapilly, M., 1973. Contribution a la faune de l'Iran; Voyages de MM. R. Naviaux et M. Rapilly (Col. Chrysomelidae). Ann. Soc. Ent. Fr. 9, 861-894 (in French).
Blossey, B., Skinner, L., 2000. Design and importance of post-release monitoring. In: Spencer, N.R. (Ed.), Proceedings of the $\mathrm{X}$ International Symposium on Biological Control Weeds, 4-14 July 1999. Montana Statue University, Bozeman, MT, pp. 693-706.

Blossey, B., Casagrande, R., Tewksbury, L., Landis, D.A., Wiedemann, R.N., Ellis, D.R., 2001. Non-target feeding of leaf beetles introduced to control purple loosestrife. Nat. Areas J. 21, 368377

Boehm, R., 1908. Notes biologiques sur quelques coléoptères de la faune désertique. Bull. Soc. Entomol. Egypt 1, 57-69 (in French).

Brown, F.B., Ruffner, G., Johnson, R., Horton, J., Franson, J., 1989. Economic Analysis of Harmful and Beneficial Aspects of Saltcedar. USDI Bureau of Reclamation, Lower Colorado Region, Report, Boulder City, Nevada. Great Western Research Inc., Mesa, AZ, $261 \mathrm{pp}$.

Brullé, A., 1832. Expedition scientifique de Moree. Zoologie (Paris) 3, 266-271 (in French).

Chen, S.H., 1961. New species of Chinese Chrysomelidae. Acta Entomol. Sinica 10, 429-435 (in Chinese with English summary).

Clement, S.L., Cristofaro, M., 1995. Open-field tests in host-specificity determinations of insects for biological control of weeds. Biocontrol Sci. Technol. 5, 395-406.

Coulson, J.R., 1992. The TAG: Development, functions, procedures, and problems. In: Charudattan, R., Browning, H.W. (Eds.), Regulations and Guidelines: Critical Issues in Biological Control, Proceedings USDA/CSRS National Workshop. Inst. Food and Agric. Sci., Univ. of Florida, Gainesville, FL, pp. 53-60.

Coulson, J.R., Vail, P.V., Dix, M.E., Nordlund, D.A., Kauffman, W.C., 2000. 110 Years of Biological Control Research and Development in the United States Department of Agriculture, 1883-1993. US Department of Agriculture, Agricultural Research Service, August 2000, Beltsville, MD.

Crins, W.L., 1989. The Tamaricaceae in the southeastern United States. J. Arnold Arboretum 70, 403-425.

Cronquist, A., 1981. An Integrated System of Classification of Flowering Plants. Columbia University Press, New York, NY.

Cronquist, A., 1988. The Evolution and Classification of Flowering Plants. Houghton Mifflin, Boston, MA.

Delfosse, E.S., 2000. Biological control: important tool for managing invasive species. Agric. Res. 48, 2.

DeLoach, C.J., 1989. Saltcedar, An Exotic Weed of Western North American Riparian Areas: A Review of Its Taxonomy, Biology, Harmful and Beneficial Values, and Its Potential for Biological Control, Petition to the USDA-APHIS Technical Advisory Group on Biological Control of Weeds. USDA-ARS, Grassland, Soil and Water Research Laboratory, Temple, TX 76502, 296 p. +4 Append. (140 p.).

DeLoach, C.J., 1990. Prospects for biological control of saltcedar (Tamarix spp.) in the riparian habitats of the southwestern United States. In: Delfosse, E.S. (Ed.), Proceedings of the VII International Symposium of Biological Control of Weeds, 6-11 March 1988. Instituto Sperimentale per la Patologia Vegetale, Ministero dell' Agricoltura e delle Foreste, Rome, Italy, pp. 307-314.

DeLoach, C.J., 1991. Saltcedar, an Exotic Weed of Western North American Riparian Areas: A Review of its Taxonomy, Biology, Harmful and Beneficial Values, and its Potential for Biological Control. USDI Bureau of Reclamation, Lower Colorado Region, Final Report. Boulder City, Nevada, 433 p.

DeLoach, C.J., 1994. Petition to Release into the Field the Leaf Beetle Diorhabda elongata from China for Biological Control of Saltcedar, Tamarix ramosissima, a Weed of Riparian Areas of the Western United States and Northern Mexico. Petition to the USDA Animal and Plant Health Inspection Service, Technical Advisory Group for the Introduction of Biological Control of Weeds, Petition No. 9406. USDA Agricultural Research Service, Temple, TX.

DeLoach, C.J., Tracy, J.L., 1997. Effects of Biological Control of Saltcedar (Tamarix ramosissima) on Endangered Species: Draft 
Biological Assessment, 17 October 1997. USDA/ARS, Temple, TX, $612 \mathrm{p}$.

DeLoach, C.J., Gould, J., 1998. Biological Control of Exotic, Invading Saltcedar (Tamarix spp.) by the Introduction of Tamarix-specific Control Insects from Eurasia. Proposal to USDI Fish and Wildlife Service, 28 August 1998. USDA Agricultural Research Service, Temple, TX, and USDA Animal and Plant Health Inspection Service, Plant Protection and Quarantine, Phoenix, AZ.

DeLoach, C.J., Carruthers, R.I., Lovich, J.E., Dudley, T.L., Smith, S.D., 2000. Ecological interactions in the biological control of saltcedar (Tamarix spp.) in the United States: toward a new understanding. In: Spencer, N.R. (Ed.), Proceedings of the X International Symposium on Biological Control of Weeds, 4-14 July 1999. Montana Statue University, Bozeman, MT, pp. 819873.

DeLoach, C.J., Gerling, D., Fornasari, L., Sobhian, R., Myartseva, S., Mityaev, I.D., Lu, Q.G., Tracy, J.L., Wang, R., Wang, J.F., Kirk, A., Pemberton, R.W., Chikatunov, V., Jashenko, R.V., Johnson, J.E., Zeng, H., Jiang, S.L., Liu, M.T., Liu, A.P., Cisneroz, J., 1996. Biological control programme against saltcedar (Tamarix spp.) in the United States of America: progress and problems. In: Moran, V.C., Hoffmann, J.H. (Eds.), Proceedings of the IX International Symposium on the Biological Control of Weeds, 19-26 January 1996, Stellenbosch. University of Cape Town, South Africa, pp. 253-260.

Dudley, T.L., DeLoach, C.J., Lovich, J.E., Carruthers, R.I., 2000. Saltcedar invasion of western riparian areas: impacts and new prospects for control. In: McCabe, R.E., Loos, S.E. (Eds.), Transactions of the 65th North American Wildlife \& Natural Resources Conference, 24-28 March, 2000, Chicago, IL. Wildlife Management Institute, Washington, DC, pp. 345-381.

Finch, D.M., Stoleson, S.H., 2000. Status, ecology and conservation of the Southwestern Willow Flycatcher. USDA Forest Service Gen. Tech. Rept, RMRS-GTR-60, Rocky Mt. Res. Station, Ogden, UT.

Gaskin, J.F., Schaal, B.A., 2002. Hybrid Tamarix widespread in U.S. invasion and undetected in native Asian range. Proc. Natl. Acad. Sci. 99, 11256-11259.

Gerling, D., Kugler, J., 1973. Evaluation of Enemies of Noxious Plants in Israel as Potential Agents for the Biological Control of Weeds, 1 Sept. 1970-31 Aug. 1973. Final Technical Report to USDA Agricultural Research Service, P.L. 480 (Project \#A10ENT-36). Tel Aviv University, Department Zoology, Tel Aviv, Israel.

Goeden, R.D., 1983. Critique and revision of Harris' scoring system for selection of insect agents in biological control of weeds. Protect. Ecol. 5, 287-301.

Griffin, G.F., Stafford Smith, D.M., Morton, S.R., Allan, G.E., Masters, K.A., 1989. Status and implications of the invasion of tamarisk (Tamarix aphylla) on the Finke River, Northern Territory, Australia. J. Environ. Manage. 29, 297-315.

Habib, R., Hasan, S.A., 1982. Insect Enemies Attacking Tamarisk, Tamarix spp., in Pakistan June 1975-June 1980. Final Report to Commonwealth Institute of Biological Control, Pakistan Station, Rawalpindi, Pakistan.

Harris, P., 1973. The selection of effective agents for the biological control of weeds. Can. Entomol. 105, 1495-1503.

Harris, P., Zwölfer, H., 1968. Screening of phytophagous insects for biological control of weeds. Can. Entomol. 100, 295-303.

Hoffmann, J.H., Moran, V.C., 1998. The population dynamics of an introduced tree, Sesbania punicea, in South Africa, in response to long-term damage caused by different combinations of three species of biological control agents. Oecologia 114, 343-348.

Horton, J.S., 1964. Notes on the Introduction of Deciduous Tamarisk. USDA-Forest Service Research Note RM-16, Ft. Collins, CO.

Horton, J.S., Campbell, C.J., 1974. Management of Phreatophyte and Riparian Vegetation for Maximum Multiple Use Values. USDA Forest Service Research Paper RM-117, Ft. Collins, CO.
Huffaker, C.B., 1957. Fundamentals of biological control of weeds. Hilgardia 27, 101-157.

Huffaker, C.B., 1964. Fundamentals of biological weed control. In: DeBach, P. (Ed.), Biological Control of Insect Pests and Weeds. Chapman and Hall, London, pp. 631-649.

Huffaker, C.B., Kennett, C.E., 1959. A ten-year study of vegetational changes associated with biological control of Klamath weed. J. Range Manage. 12, 69-82.

Hunter, W.C., 1984. Status of Nine Birds Species of Special Concern Along the Colorado River. Wildlife Branch Administrative Report No. 84-2. Federal Aid in Wildlife Restoration Project W-65-R-1 (554), Nongame Wildlife Investigations; California Department of Fish and Game, Resources Agency. Wildlife Extension, University of California, Davis.

Julien, M.J., Griffiths, M.W., 1999. Biological Control of Weeds: A World Catalogue of Agents and their Target Weeds, fourth ed. CABI Publishing, Wallingford, Oxon OX10 8DE, UK.

Kartesz, J.T., Meacham, C.A., 1999. Synthesis of North American Flora, Digital Ver. 1.0. North Carolina Botanical Garden. University of North Carolina, Chapel Hill, NC.

Kocher, L., 1958. Catalogue Commente des Coleopteres du Maroc, Fascicule VII, Phytophages. Travaux de l'Institut Scientifique Cherifien, Serie Zoologie No. 19. Royaume du Maroc [in French]. Rabat, Morocco.

Kovalev, O.V., 1995. Co-evolution of the Tamarisks (Tamaricaceae) and Pest Arthropods (Insecta; Arachnida: Acarina) with special reference to biological control prospects. In: Proceedings of Zoological Institute, Russian Academy of Sciences, St. Petersburg, vol. 259. Pensoft Publishers, Moscow.

Kulinich, P.N., 1962. On the biology of insects harmful to Tamarix in Tajikistan. Izv. Otd. Biol. Nauk. Akad. Tadzhikskoi SSR 4, 1-75 (in Russian).

Laboissière, V., 1934. Galerucinae de la faune Francaise (Coléoptères). Ann. Soc. Ent. France 103, 1-108 (in French).

Lewis, P.A., DeLoach, C.J., Herr, J.C., Dudley, T.L., Carruthers, R.I., 2003a. Assessment of risk to native Frankenia shrubs by the Asian leaf beetle, Diorhabda elongata deserticola (Coleoptera: Chrysomelidae), introduced for biological control of saltcedars (Tamarix spp.) in the western United States. Biol. Control (in press).

Lewis, P.A., DeLoach, C.J., Knutson, A.E., Tracy, J.L., Robbins, T.O., 2003b. Biology of Diorhabda elongata deserticola (Coleoptera: Chrysomelidae), an Asian leafbeetle for biological control of saltcedars (Tamarix spp.) in the United States. Biol. Control (in press).

Liu, M.T., Zhang, P., 1987. Resource of Tamarix plants and their utilization in Xinjiang. In: Anon (Ed.), Technical Report on the Studies of Tamarix spp. Chinese Academy of Agricultural Science of Xinjiang, Institute of Biology, Pedology and Desert Science, Urumqi, People's Republic of China (in Chinese).

Lopatin, I.K., 1977. The Leaf-Beetles of Middle Asia and Kazakhstan. Nauka Publishing, Leningrad (1984 English translation from the Russian, Amerind Publishing Company, New Delhi).

Lovich, J.E., de Gouvenain, R.C., 1998. Saltcedar invasion in desert wetlands of the southwestern United States: ecological and political implications. In: Majumdar, S.K., Miller, E.W., Brenner, F.J. (Eds.), Ecology of Wetlands and Associated Systems. Pennsylvania Academy of Science, Easton, Pennsylvania, pp. 447-467.

Lozovoi, A.I., 1961. Tamarisk and insect damage to it in dry regions of eastern Georgia. Vest. Tbilissk. Bot. Sada., Akad, Nauk. Gruzinsk SSR 67, 83-89 (in Russian).

Lucas, P.H., 1849. Exploration scientifique de l'Algeria. Zoologie (Paris) 2, 542-546 (in French).

Luck, R.F., Schriven, G.T., 1976. The elm leaf beetle, Pyrrhalta luteola, in southern California: its pattern of increase and its control by introduced parasites. Environ. Entomol. 5, 409416. 
Lundberg, S., Palm, T., Trottestam, O., 1987. Coleoptera from the northern Sicilian Coast. II. Grass-land, river mouths, sea shores, etc.. Entomol. Tidskr. 108, 123-129 (in Swedish).

Medvedev, L.N., 1982. Chrysomelids of Mongolia. Nauka Moscow, USSR (in Russian).

Medvedev, L.N., Roginskaya, E.Ya., 1988. Catalogue of the Hostplants of the Leaf Beetles of the USSR. Academy of Sciences of USSR, Moscow, USSR (in Russian).

Mityaev, I.D., 1958. A review of insect pests of Tamarix in the Balkhash-Alakul depression. Trudy Inst. Zool. Akad. Nauk. Kazakh. SSR 8, 74-97 (in Russian).

Mityaev, I.D., Jashenko, R.V., 1997. Biological Control of Tamarix: Annual Report for 1997. (Report to USDA Agricultural Research Service, Weed Biological Control Laboratory, Temple, TX.) Laboratory of Entomology, Institute of Zoology, Kazakhstan Academy of Sciences, Almaty, Kazakhstan.

Mityaev, I.D., Jashenko, R.V., 1998. Biological Control of Tamarix: Annual Report for 1998. (Report to USDA Agricultural Research Service, Weed Biological Control Laboratory, Temple, TX.).

Mityaev, I.D., Jashenko, R.V., 2001. Biological Control of Tamarix: Annual Report for 2001. (Report to USDA Agricultural Research Service, Weed Biological Control Laboratory, Temple, TX.).

Müller, G., 1949-1953. I Coleotteri della Venezia Guilia, vol. 2, Phytophaga, Library ed.. Tricste, Italy (in Italian).

Nechols, J.R., Andres, L.A., Beardsley, J.W., Goeden, R.D. Jackson, C.G., 1995. Biological Control in the Western United States. Accomplishments and Benefits of Regional Research Project W-84, 1964-1989. University of California, Oakland, CA, Division of Agriculture and Natural Resources Publication 3361.

Normand, H., 1936. Contribution au catalogue des Coleopteres de la Tunisie. Bull. de la Soc. D'Hist. Nat. de l'Afr. Du Nord 28, 116-143 (in French)

Norusis, M.J., 1988. "SPSS/PC+ V2.0 Base Manual”. SPSS, Chicago, IL.

Pemberton, R.W., Hoover, E.M., 1980. Insects Associated with Wild Plants in Europe and the Middle East: Biological Control of Weeds Surveys. USDA, Washington, DC.

Peyerimhoff (de), P., 1926. Notes sur la biologie de quelques Coléoptères Phytophages du Nord-Africain (Ivème sér.). Ann. Soc. Entomol. France 95, 319-390 (in French).

Pimentel, D., 2000. Biological control of invading species. Science 289, 869.

Pimentel, D., Acquay, H., Biltonen, M., Rice, P., Silva, J., Nelson, J., Lipner, V., Giordano, S., Horowitz, A., D’Amore, M., 1992. Environmental and economic costs of pesticide use. Bioscience 42, 750 .

Rees, N.E., Quimby, P.C., Piper, G.L., Turner, C.E., Coombs, E.M., Spencer, N.R. Knutson, L.V., 1996. Biological Control of Weeds in the West. Western Society Weed Science, Montana Department Agriculture, USDA-Agricultural Research Service, and Montana State University, Bozeman, Montana.

Regalin, R., 1997. Notes on Chrysomelidae of Crete (Greece) and description of Lachnaia (Lachnaia) zoiai n. sp. (Coleoptera, Chrysomelidae). Boll. Soc. Entomol. Ital. 129, 67-77 (in Italian).

Robinson, T.W., 1965. Introduction, spread and areal extent of saltcedar (Tamarix) in the western states. USDI Geol. Surv. Professional Paper 491-A, 1-12+ map.

Rusanov, F.N., 1949. The Middle Asian tamarisks. Izv. Akad. Nauk Uzbek SSR, Tashkent (in Russian).

Samedov, N.G., Mirzoeva, N.B., 1985. A review of the leaf-beetles (Coleoptera, Chrysomelidae) of the tugai forests in Azerbaijan. Entomologicheskoe Obozrenie 64 (4), 705-715 (in Russian)

SAS Institute, 1990. SAS/STAT User's Guide, vol. 2, GLM-VARCOMP. SAS Institute, Cary, NC.

Seitova, M.N., 1974. To the entomofauna inhabiting Ammodendron argenteum Pall. (Ktze) in the Sary-Taukum Desert. Fauna, Systematics, and Biology of Insects of Kazakhstan. Trans. Inst.
Zool. 35, 137-142, Academy of Sciences of the Kazakh SSR, Alma Ata (in Russian).

Sha, P., 1991. Preliminary study on Diorhabda elongata deserticola Chen: Biological characteristics and control methods. Turpan Area Forest Administration Station, Turpan, Xinjiang Province, P.R. China. Technical Report (in Chinese).

Sinadsky, Y.V., 1960. Halimodendron halodendron pests in bottomland forests of the Syr-Darya, south Kazakhstan region. Zhool. Zhurn. 39, 527-533 (in Russian).

Sinadsky, Y.V., 1968. Dendrophilous Insects of Middle Asian and Kazakhstan Deserts and Pest Management. Nauka Publishing House, Moscow (in Russian).

Sisneros, D., 1990. Vegetation Management Study: Lower Colorado River. Appendix II: Herbicide Analysis. Report, USDI Bureau of Reclamation. Denver, Colorado.

Spichiger, R., Savolainen, V., 1997. Present state of Angiospermae phylogeny. Candollea 52, 435-455.

Stein, B.A., Flack, S.R., 1996. America's least wanted: alien species invasions of U.S. ecosystems. The Nature Conservancy Nov.-Dec. $17-23$.

Stenquist, S.M., 2000. Saltcedar integrated weed management and the endangered species act. In: Spencer, N.R. (Ed.), Proceedings of the $\mathrm{X}$ International Symposium on Biological Control of Weeds 4-14 July 1999. Montana State University, Bozeman, Montana, pp. 487-504.

Sukopp, H., Trautmann, W., 1981. Causes of the decline of threatened plants in the Federal Republic of Germany. In: Synge, H. (Ed.), The Biological Aspects of Rare Plant Conservation. Wiley, New York, pp. 113-116.

Tomov, V., 1969. A new genus and species (Diorhabda elongata (Brullé)) for the fauna of Bulgaria (Galerucinae, Chrysomelidae, Coleoptera). Nauchi Trud. Vissh ped. Inst. Plovdiu 7, 181-182 (in Bulgarian)

Tracy, J.L., DeLoach, C.J., Biological control of saltcedar in the United States: progress and projected ecological effects. In: Bell, C.E. (Ed.), Arundo and Saltcedar: The Deadly Duo, Proceedings of the Arundo and Saltcedar Workshop, 17 June, 1998, Ontario, California. 1999, pp. 111-154.

USDA-Animal and Plant Health Inspection Service. 1999a. Reviewer's Manual for the Technical Advisory Group for Biological Control Agents of Weeds: Guidelines for Evaluating the Safety of Candidate Biological Control Agents, USDA, APHIS, PPQ, Manuals Unit, Frederick, Maryland.

USDA-Animal and Plant Health Inspection Service, 1999b. Availability of a draft Environmental Assessment and Finding of No Significant Impact. Fed. Register 64, 13395-13396.

USDI-Fish and Wildlife Service, 1995. Endangered and threatened wildlife and plants; final rule determining endangered status for the southwestern willow flycatcher. Fed. Register 60, 10964 10715.

Wapshere, A.J., 1974. A strategy for evaluating the safety of organisms for biological weed control. Ann. Appl. Biol. 77, 201-211.

Wilcove, D.S., Rothstein, D., Dubow, J., Phillips, A., Losas, E., 1998. Quantifying threats to imperiled species in the United States. BioScience 48, 607-615.

Yakhontov, V.V., Davletshina, A.G., 1959. Review of the insect fauna damage to sand-binding plants in the ancient delta of Amu-Darya River. In: Anon. (Ed.), Proceedings on Economic Possibilities of Uzbekistan. No. 10, Academy of Science of Uzbek, SSR, Tashkent, Uzbek SSR, pp. 326-342 (in Russian).

Zavaleta, E., 2000. The economic value of controlling an invasive shrub. Ambio 29, 462-467.

Zocchi, R., 1971. Contributo alla conoscenza dell'entomofauna delle tamerici i Italia. Redia 52, 31-129 (in Italian).

Zwölfer, H., Harris, P., 1971. Host specificity determination of insects for biological control of weeds. Annu. Rev. Entomol. 16, 159-178. 